\title{
THE SYMPTOM-COMPLEX OF THE ACUTE POSTERIOR POLIOMYELITIS OF THE GENICULATE, AUDITORY, GLOSSOPHARYNGEAL AND PNEUMOGAS- TRIC GANGLIA
}

\author{
J. RAMSAY HUNT, M.D. \\ NEW YORK
}

In previous communications ${ }^{1}$ I have already elaborated in some detail the symptomatology and complications of the posterior poliomyelitis of the geniculate ganglion of the facial nerve; a syndrome which is characterized by herpes zoster oticus, facial palsy and auditory symptoms. When the ganglion alone is involved, herpes oticus results, the eruption being distributed in the central portions of the external ear. If the infiammation extends from the ganglion to the nerve-trunk, facial palsy follows; and when deafness and symptoms of Ménière's disease occur they are produced either by an extension of the inflammatory process to the adjacent auditory nerve or by simultaneous involvement of the peripheral auditory ganglia (Fig. 1).

I shall now consider the localization of the same process in the peripheral root ganglia of the glossopharyngeal, vagus, and auditory nerves, their respective neural complications and the various clinical combinations which may occur. ${ }^{2}$ I shall also endeavor to differentiate the zoster zones of the geniculate, glossopharyngeal, and vagal ganglia on the external ear, and within the buccal cavity. It may be said in general that all of these clinical types are related, and together form a definite group of cases, which is characterized by herpes zoster of the cephalic extremity, with facial palsy, auditory, and pneumogastric symptoms in various combinations.

This group forms an interesting chapter of herpes zoster, an affection which is distinguished by an eruption of herpetic vesicles, usually unilateral, and strictly limited to a definite area of the skin or mucous membrane (the zoster zone). The underlying lesion is an inflammation in

1. Hunt, J. Ramsay: Herpetic Inflammation of the Geniculate Ganglion; a New Syndrome and Its Complications, Jour. Nerv. and Ment. Dis., 1907, xxxiv, 73 ; id., Otalgia Considered as an Affection of the Seventh Cranial Nerve, Arch. Otol., 1907, xxxvi, 371 ; id., Ein Fall von Poliomyelitis posterior des Ganglion Geniculi, Neurol. Centralbl., 1908, xxvii, 514.

2. Hunt, J. Ramsay: The Paralytic Complications of Herpes Zoster of the Cephalic Extremity; a Preliminary Report on the Herpetic Inflammations of the Geniculate, Glossopharyngeal, Vagal and Acoustic Ganglia, Jour. Am. Med. Assn., 1909, liii, 1456. 
the sensory ganglion or ganglia corresponding to the eruption. The eruption is usually confined to the distribution of a single ganglion, but this is not always so, and double, triple, and even multiple forms occur. The region of the head and neck is especially liable to involvement of more than one ganglion in zona.

In my previous papers, I have particularly emphasized the occasional presence of inflammatory reactions in those ganglia situated immediately

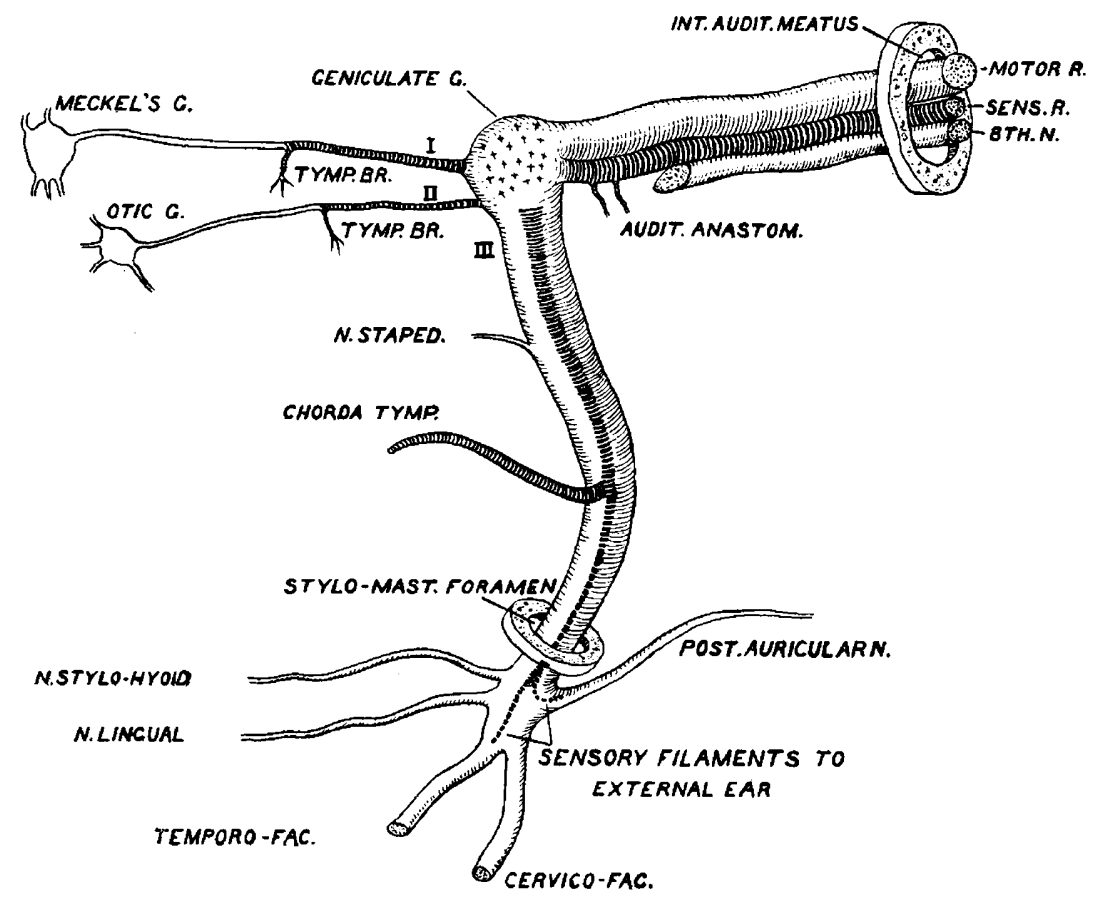

Fig. 1.-Diagrammatic representation of the facial nerve, showing its ganglion, motor and sensory roots, and peripheral divisions. Division I: The great superficial petrosal nerve passing to Meckel's ganglion, with its tympanic branch (great deep petrosal). Division II: The small superficial petrosal nerve passing to the otic ganglion, with its tympanic branch (small deep petrosal). Division III: Including the motor trunk, chorda tympani and sensory filaments for the external ear.

above or below the chief or eruptive focus; or that corresponding to the zoster zone. I would draw attention again to this serial involvement of ganglia as having an important bearing on the neural complications which are to be considered later.

The specific infective agent of zona is unknown, but whatever its nature may be, it possesses a definite and special affinity for certain ganglionic structures, of which the posterior root ganglia of spinal nerves 
and the Gasserian ganglia are types. It produces in these structures an inflammation, having the same general pathological characteristics as the acute anterior poliomyelitis. Because of the similarity between these two inflammatory affections, one of the anterior horns, the other of the posterior ganglionic chain, herpes zoster has been termed an acute posterior poliomyelitis (Head and Campbell ${ }^{3}$ ).

It is now generally accepted by anatomists that the geniculate, glossopharyngeal, pneumogastric, and even the acoustic ganglia, are homologues of the posterior spinal ganglia, and form an integral part of this ganglionic chain. For this reason, I believe that these ganglia may also be involved in the specific infection and inflammatory reactions of zona (posterior poliomyelitis). Recent investigations have shown that the acute anterior poliomyelitis occasionally invades the motor cranial nerve ganglia; the same is also true of posterior poliomyelitis and the various root ganglia of the seventh, eighth, ninth and tenth nerves, giving rise to a series of interesting syndromes, the real nature and significance of which have not been recognized.

The nerve complications which arise, like the herpetic eruption, are unilateral, and are produced by an extension of the inflammatory process in the ganglion to the adjacent fibers of the seventh, eighth, ninth and tenth nerves. These may occur with the outbreak of the eruption, or, as more commonly happens, several days, or even a fortnight, later. This period of quiescence or latency, intervening between the appearance of the eruption and that of the nerve involvement, suggests that the inflammatory process in the ganglion may be more or less progressive in character in its earlier stage, and has not reached its full height with the appearance of the vesicles. This tendency to slight progression receives a further clinical corroboration from the occurrence of successive crops of vesicles in the earlier period of the disease.

The clinical statistics which are utilized in my paper are based on the records of eighty-seven cases of herpes zoster of the cephalic extremity, in which there was an associated facial palsy. In this entire series, the eruption was limited to one or more of the zoster zones of the head and neck. Among these cases there were many with auditory complications, and a few with symptoms pointing to involvement of the pneumogastric nerve. In order to illustrate the various clinical types, my own unpublished cases will be presented in abstract form, together with certain cases recorded by other observers illustrating special features of the disease.

The subject-matter will be considered under the following general headings :

3. Head, H., and Campbell: Pathology of Herpes Zoster, Brain, 1900, xxiii, 3533. 
1. Report of personal cases of herpes zoster oticus.

2. The zoster zones of the geniculate, glossopharyngeal, and vagal ganglia on the external ear (herpes zoster oticus).

3 . The paralytic complications of herpes zoster oticus.

4. The intra-oral zoster zones of the glossopharyngeal, and vagal ganglia (herpes zoster pharyngis and herpes zoster laryngis).

5. The complications of herpes zoster pharyngis and herpes zoster laryngis.

6. Herpes zoster of the tongue with facial palsy.

$\%$. Posterior poliomyelitis of the auditory ganglia.

8. The paralytic complications of herpes zoster facialis and herpes zoster occipitocollaris.

9. Concluding remarks.

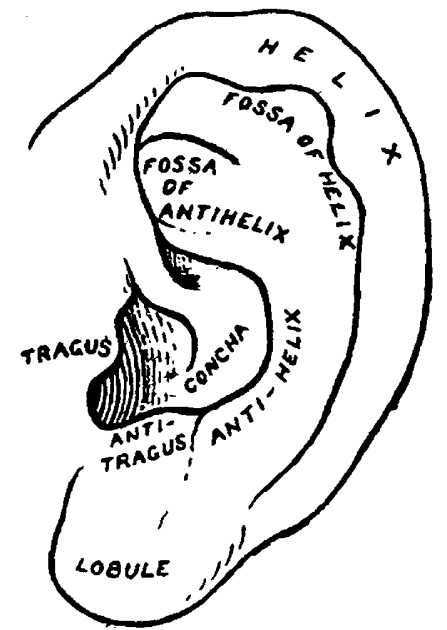

Fig, 2.-The topographical landmarks of the external ear.

\section{REPORT OF PERSONAL CASES OF HERPES OTICUS}

CASE 1.-Herpes Zoster Oticus.-(Neurological service of Prof. Dana, Cornell Medical School). W. F., aged 16, in good health. Onset Nov. 16, 1907, with headache, chilly sensations and pain in the occipital region. The patient was unable to work and remained at home several days; there was no vomiting but considerable nausea with fever. The patient was examined in the Cornell Medical Clinic, November 20. On admission his temperature was 102; pulse 108 . There was an eruption of herpes in the left ear which had made its appearance on November 17. There was no discharge from the ear, and the hearing was not affected; there was no tinnitus aurium. The eruption had the following distribution: A small group on the posterior half of the concha; a somewhat larger group immediately posterior to this on the antihelix; another on the posterior portion of the antihelix and one just beneath its fold, in the postero-superior boundary of the concha. The auricle was somewhat swollen. There was no eruption within the canal; no vesicles on the face or neck. The innervation of the facial nerve was equal on the 
two sides. Objective examination of the ear was negative. There was some hypalgesia in the region of the eruption.

Case 2.-Herpes Zoster Oticus.-(Referred from the New York Eye and Ear Infirmary. Service of Dr. Whiting.) Mrs. L., aged 22, in good health. Onset Monday, Jan. 4, 1909, with roaring in the right ear. During the day there were severe pains in the auditory canal and mastoid region. The next day, the lower half of the auricle became swollen, tender and bluish-red in color, and an eruption made its appearance in the swollen area. A few enlarged tender glands were palpable below the auricle. The tinnitus aurium continued for several days and the hearing was slightly reduced on the affected side. The eruption had the following distribution: the antitragus and the helix immediately above and the lobule immediately below the antitragus. All trace of the vesicles disappeared in two weeks. The canal and tympanum were free from vesicles, as were also the face and neck.

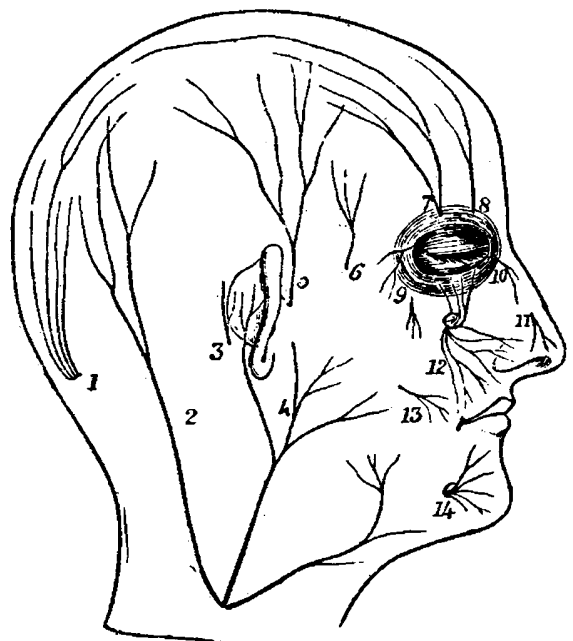

Fig. 3.-Diagram of the sensory nerves of the sealp and face; (1) great occipital; (2) small occipital; (3) auricular branch of the pneumogastric; (4) great auricular; (5) auriculotemporal; (6) temporal branch of superior maxillary nerve; (7) supra-orbital ; (8) supratrochlear; (9) malar branch of superior maxillary nerve; (10) infratrochlear; (11) nasolobular; (12) infra-orbital; (13) buccal branch of inferior maxillary nerve; (14) mental. (From Holden's Anatomy.)

Case 3.-Herpes Zoster Oticus.-(Referred from the Otological Clinic of the Cornell Medical School by Dr. MeAuliffe.) Miss F., aged 18, in good health. Onset in August, 1908, with severe pains in the lobule of the left ear and in the depth of the auditory canal; of a sharp, shooting character. On the third day there appeared several small groups of herpetic vesicles on the posterior mesial surface of the auricle and the adjacent mastoid region, corresponding to the distribution of the auricular branch of the vagus. There was no tinnitus and the hearing was undisturbed. Canal and tympanum were free. The eruption desiccated and disappeared, leaving a few small scars. The neuralgic pains (postherpetic otalgia) persisted for a long time and were very severe. Six months 
later, the patient was still subject to nuralgic pains in the ear, very sharp and shooting in character and causing a distinct reflex jerk of the head. The hearing was normal.

Comment.-This case is interesting because of the persistent and severe postherpetic otalgia and the localization of the herpetic vesicles, posteriorly, in the cleft between the auricle and mastoid process, within the distribution of the auricular branch of the vagus (Fig. 3 ).

CASE 4.-Herpes Zoster Oticus with Facial Palsy.-(Referred from the New York Eye and Ear Infirmary, by Dr. Robert G. Reese). J. M., aged 19, was exposed to cold on Feb. 1, 1909; this was followed by coryza and chilly sensations. The next day there were pains in the depths of the left ear, concha and mastoid region, which were so severe during the night that the patient could not sleep. On February 5 , there was a paralysis of the left side of the face; but no tinnitus, and the

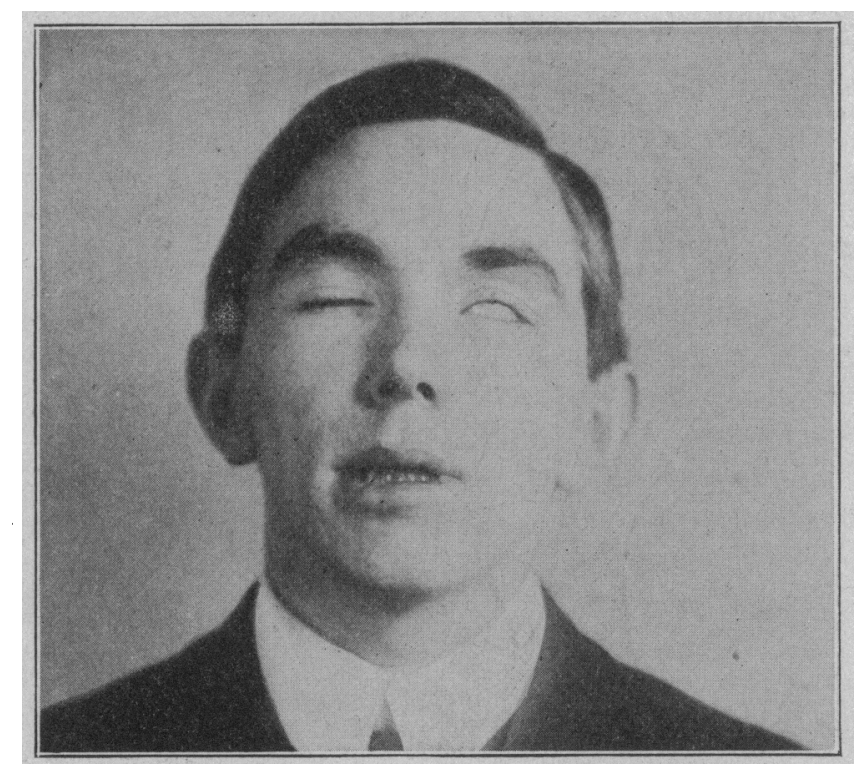

Fig. 4 (Case 4).-Peripheral facial palsy in conjunction with an eruption of herpes zoster in the cleft between the auriele and the mastoid process, in the dis. tribution of the auricular branch of the vagus.

hearing was undisturbed (Fig. 4). Examination on February 9 showed complete facial palsy with ageusia in the distribution of the left chorda tympani. Hearing was normal. An eruption of herpes zoster was distributed posteriorly in the cleft between the auricle and mastoid region. (See Fig. 5.)

Comment.-This case is interesting because of the situation of the eruption in the distribution of the auricular branch of the vagus, and the associated facial palsy, which I attribute to an inflammatory reaction in the geniculate ganglion of the seventh nerve.

CaSe 5.-Herpes Zoster Oticus with Facial Palsy.-(Referred by Dr. Josephine Walter of New York City.) Miss S., aged 30, in good health. Onset the last week 
in October, 1909, with neuralgic pains in the right ear, occipital region and right side of the face. A few days later, "a sore throat on the right side which was slightly swollen and inflamed." (Examination by ship-surgeon.) At the same time there appeared a small group of herpetic vesicles in the concha of the right ear. The antitragus was swollen, red and tender. A right facial palsy appeared on November 6; hearing normal. November 26, the facial innervation was gradually improving on the right side, although evidences of paresis in all three branches were still present; hearing normal; taste normal. The desiccated

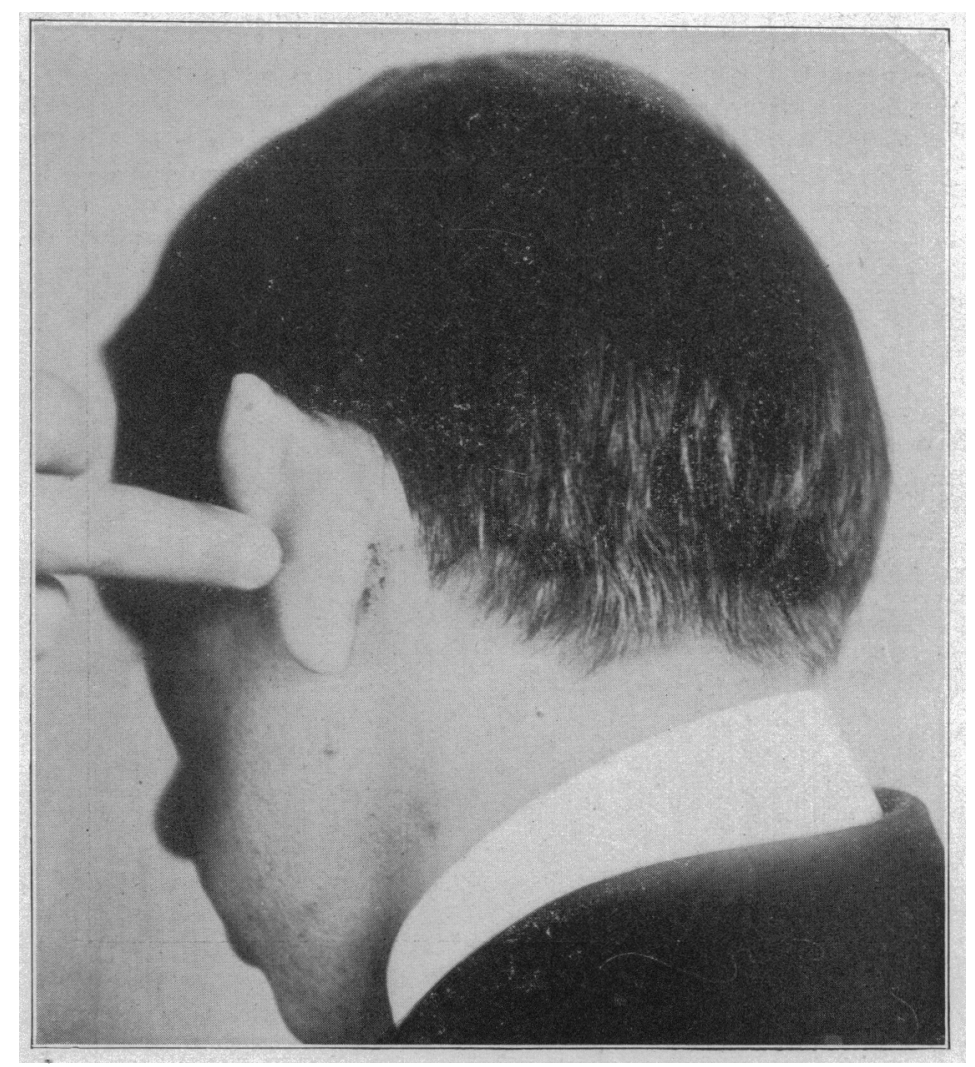

Fig. 5 (Case 4).-An eruption of herpes zoster, limited to the distribution of the vagus on the posteromesial surface of the auricle, and adjacent mastoid.

remains of the vesicles were still evident in the conchal region; none within the auditory canal. Neuralgic pains still persisted in the ear. There was a distinct paresis of the soft palate on the affected side, and on innervation the uvula was drawn upward and to the left.

Comment.-This case is of interest because of the localized "sore throat" on the right side and the associated paresis of the right sile of the soft palate in conjunction with herpes oticus and seventh nerve palsy. 
Case 6.-Herpes Zoster with Facial Palsy.-(Referred by Dr. N. R. Norton of New York.) Miss F., aged 22. Onset Oct. 24, 1909, with neuralgic pains in and about the left ear, and when severe, radiating through the left side of the face and head. From the first, there was also tinnitus aurium and a distinct sensitiveness to high-pitched sounds (hyperacusis). A few days later, a small group of herpetic vesicles made their appearance and were distributed on the floor of the auditory canal at the entrance to the meatus, in the concha and beneath the fold of the antihelix. On November 7 , a left facial palsy appeared. Examination on November 11 showed a paralysis of the left side of the face; all branches were involved; hearing normal. Taste lost in the left ehorda distribution. Tear secretion was increased on the left side. (Inhalation of oil of mustard.) Palate innervation normal. On November 18, facial palsy was much improved, only a trace remaining; still occasional slight pains in the ear.

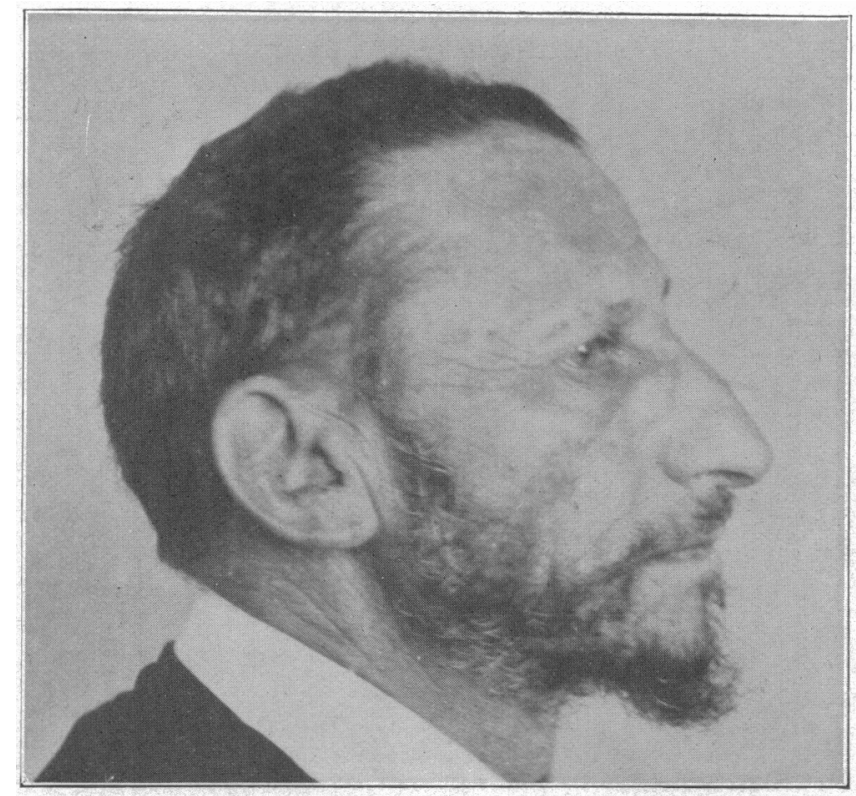

Fig. 6 (Case 8).-Herpes zoster oticus with facial palsy. The herpetic vesieles are situated on the tragus, antitragus, concha and the lobule. Swelling and edema of the central part of the auricle.

Comment.-In this case, hyperacusis and tinnitus aurium had definitely preceded the onset of facial palsy, and so cannot be attributed to an interference with the action of the stapedius muscle, as in oxyecoia; it may therefore be regarded as a mild expression of auditory nerve irritation.

Case 7.-Herpes Zoster Oticus with Facial Palsy.-(Referred by Dr. E. G. Zabriskie of New York.) Mrs. S. K., aged 50. Onset October 29, with sharp, shooting pains in the left side of the head, in the occipital and temporal regions. On Wednesday, the pains were severe and chiefly centered in the mastoid region, just behind the auricle. On Wednesday evening, a left facial palsy was apparent; there was also an itching in the auricle and an eruption of herpes zoster. No 
discharge from the ear; no disturbances of hearing. The eruption was distributed as follows: a small group on the antitragus; another on the posterior half of the concha; a small patch at the entrance to the external meatus and a group on the anterior half of the concha; a somewhat larger group on the posterior boundary of the concha, just beneath the fold of the antihelix. Examination November 2; there was complete left facial palsy. Hearing normal; the uvula hung distinctly toward the left, and there was a noticeable paresis of the innervation of the left side of the palate. The sense of taste was lost in the left chorda distribution. There are still sharp shooting pains in the auricle, depths of the ear and mastoid region.

Comment.-It is interesting to note that in this case also there was a distinct weakness in the innervation of the soft palate on the affected side.

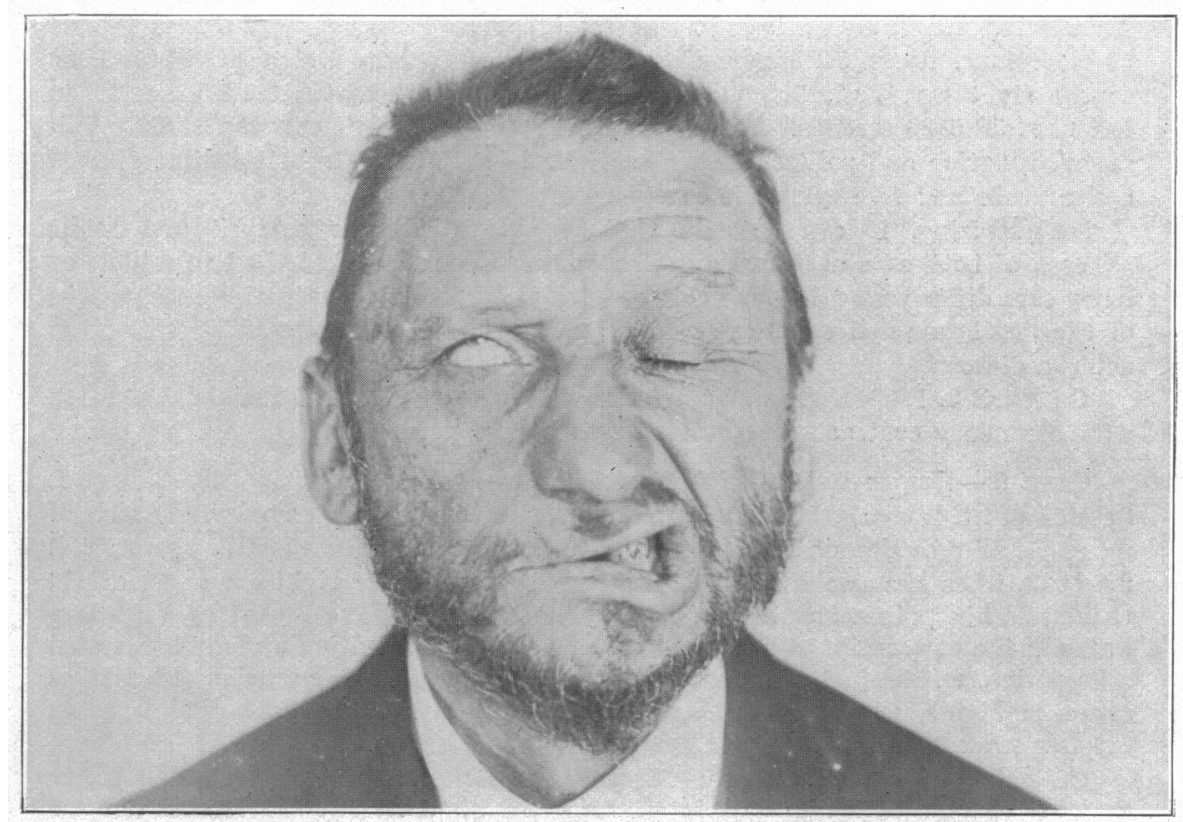

Fig. 7 (Case 8):-Complete right facial palsy, complicating herpes zoster in the geniculate zone, edema and slight lateral dislocation of the right auricle.

Case 8.-Herpes Oticus with Facial Palsy.-(Referred by Dr. I. Abrahamson of New York.) J. H. C., aged 68, in good previous health. Onset Friday, Oct. 16, 1907, with deep-seated pains in the mastoid region and depths of the right ear. The next day the auricle became swollen and the seat of an herpetic eruption. Small groups of vesicles were situated on the tragus, antitragus and immediately below on the lobule; also a group on the posterior portion of the concha and the superior surface of the antihelix (Fig. 6). There was also a single large vesicle on the posterior portion of the tympanic membrane. The pains were continuous and very severe at night, the auricle was swollen and tender. On October 18, a right facial palsy appeared, and tinnitus with diminution of hearing on the affected side (Fig. 7). Examination on November 1, complete right facial palsy 
with reactions of degeneration; hypesthesia of the right side of the face; conjunctival reflex present. lalate innervation, normal. Tear secretion present on both sides.

Otologic examination by Dr. W. S. Bryant, as follows: Right auricle slightly more prominent than the left. Edematous and tender, especially about the concha. Some thin erusts on the floor of the concha and antitragus. Canal much smaller than on the other side. Fundis of canal bright red, swollen and leaking bloody serum. The membrana tymphani : anterior half elear, posterior half involved in swelling of canal. Jumen of inner end of canal reduced to one-third of the size of its fellow. Slight tenderness half an inch behind mastoid antrum. Left ear shows advanced chuonic middle-ear catarh with retraction and contraction of the drum membrane and some thickening. Light reflex nearly absent. Tinnitus in right ear only. Functional tests: High tone limit, right ear, 12,500 vib.; left ear. 10,600 vib. Jow tone limit appears to be the same in both ears, between 67 and 59 vibrations. Fork, 512 single vibrations. was referred from all parts of the head to the right ear. Fork 512 vibrations: on the right mastoid $8 / 30$ seconds; on left mastoid $5 / 30$ seconds. Watch: right ear was $4 / 36$; left ear was $11 / 36$. Val. salva's inflation and politzerization, negative in both ears. Catheterization showed a clear tube and free tympanic eavity on the right.

Summarizing, it can he said that chronic middle-ear catarrh and senile changes of both ears are narked. There is no indication that the two middle or inner cars differ very much in their condition. The sound condueting mechanisms of the membrane and canal are afrected on the right; with myingitis and otitis externa diffusa.

On April 3, 1908, there was persistent weakness of the right facial innervation with secondary contractures; hearing normal; no pain.

CASE 9.-Herpes Oticus with Facial l'alsy.--(Otservation by Dr. Sidney I. Schwab of St. Jouis.) Miss D., aged 28. A previous history of old ear trouble of many years' duration on both sides. Patient was in hes ustial health up to April 28, 1909 , when she awoke in the morning with pain in the right ear and mastoid region. This pain was accompanied by headache and some general weakness. Pains in the ear continued and were very severe. Examination on May 2 revealed a herpetic eruption in the external auditory caral, and on the concha. There was also a right facial palsy. Pain sense on the right side of face was diminished in the trigeminal distribution. (Hypalgesia.)

Otological report as follows: Both ears: Bone conduction decidedly better than air conduction. (Only ( 4 luard better by air conduction.) Jength of time tuning-fork hoard by air decidedly decreased, bone only slightly decreased. Fork placed on median line of head always lateralized to right side.

Left ear: Old kidney-shaped perforation in drum below handle of hammer which was partly destroyed. Spech 6.0 neters, whisper 0.5 meter. After politzerjzation, speech $-6.0 \mathrm{~m}$. whisper more than 0.75 meter.

Right ear: 6-8 small ulcers in different stages of resolution seen on the auricle, chicfly on the erest of the antihelix, although there were a couple in the concha. The meatal walls were slightly redder than normal. The drum showed an old cicatrix, occupying the anterior inferior quadrant and part of the posterior inferior. The remainder of the drum was diffusely redlened, except for a small red spot over the handle of the hammer just below the short process. 'The drum was, as a whole, retracted, the handle being almost horizontal. Hearing, speech -0.05 meter; whisper not heard; after politzerization, speech 0.5 plus meter. whisper not heard. The sensitiveness of the neatus and drum was normal. The mastoid was hypersensitive, especially over the antrum. 
Otological diagnosis: Otitis melia suppurativa ehronica antiqua on left. Herpes aurieule auris et myringis + otitis media catarrhalis chronica on right.

Comment.-Fight weeks later, the facial palsy had disappeared, save for a slight weakness in the lower branch.

Of these nine cases of herpes zoster oticus, it will be observed that the eruption was distributed in the central portions of the external surface of the auricle in seven cases (geniculate area), and on the posteromesial surface of the auricle and adjacent mastoid region in two cases (vagus area).

In the first group there was an associated facial palsy in five cases. Facial palsy was present in one of two cases in which the eruption was distributed in the postauricular cleft.

In none of the cases was the acoustic nerve involved, except (Case 6, in which tinnitus aurium and hyeracusis preceded the facial palsy.

It is interesting that in two cases with facial nerve palsy, a clistinct paresis of the soft palate was observed on the affected side.

I shall now consider in detail the question of the aurjeular zoster zones.

2. THE ZOSTER ZONES OF THE GENTCULATE, GLOSSOPHARYNGEAL AND VAGAL GANGLIA ON THE EXTERNAL EAR (HERPES ZOSTER OTICUS)

In my carlier contributions to this subject, ${ }^{4}$ I pointed out the existence of a group of cases, with an isolated eruption of herpes zoster on the external ear, caused by a posterior poliomyelitis of the geniculate ganglion. 'The resicles in this group of cases were very sparsely distributed within an irregularly cone-shaped zone corresponding to the following anatomical landmarks of the external ear: i. e., the tympanic membrane, external auditory canal and meatus, concha, antihelix, and fossa of the antihelix, the tragus, antitragus, and the lobuie.

This cone-like area is situated between the zone of the Gasserian in front, and those of the cervical ganglia belind. At that time I also expressed the belief that the ganglia of the glossopharyngeal and ragus nerves have a representation within this area as well.

I shall now proceed to a further consideration of this question, and shall endeavor to differentiate these various zones on the auricle, which, if still somewhat crude and unsatisfactory, mas direct attention to the subject and serve as a guide in future investigations. The evidence on

4. Hunt, J. Ramsay: A Further Contribution to the Herpetic Inflammations of the Geniculate Ganglion, Am. Jour. Med. Sc., 1908, exxxi, 226. 
which I shall base the separation of these otic zones has been considerably abbreviated for purposes of presentation, and is anatomical, embryological and clinical in its nature.

\section{ANATOMTCAL CONSIDERATIONS (TILE SENSORY INNERVATION OF THE EXTERNAL EAR)}

The external ear is distinguished by a peculiarly complex and intricate sensory innervation; four cranial and two spinal ganglia participating in its nerve supply. The difficulty of the subject is still further increased by the small, almost vestigial distributions of some of the ganglia represented, as well as by the normal variation and overlap of sensory zones, which is considerable in this region.

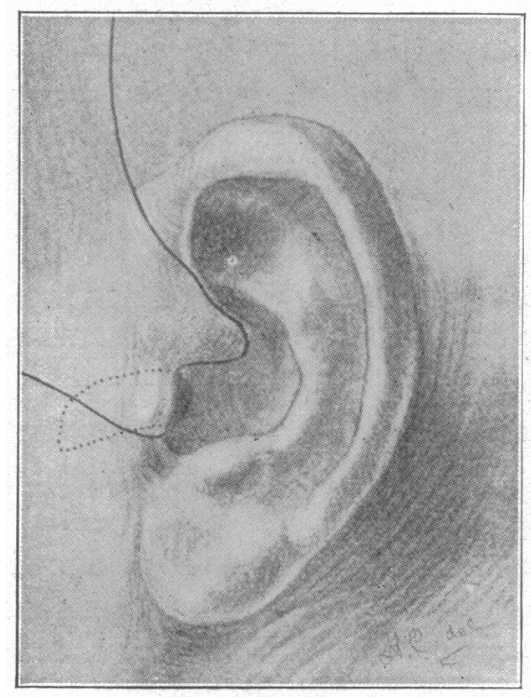

Fig. 8.-Outlines of the auricular portion of the trigeminal field determined by the line delimiting tactual anesthesia. (After Cushing.)

The nerve-supply of the auricle may be summarized as follows: The Gasserian ganglion is represented by auricular filaments which arise from the auriculotemporal branch of its third division; the gericulate, by auricular fibers, which emerge with the facial at the stylomastoid foramen, the exact course and distribution of which are at present unknown; the petrous ganglion of the ninth, and the jugular ganglion of the tenth, by their respective auricular branches; and the second and third cervical ganglia, by the auricular branches of the cervical plexus. There are numerous anastomoses between these various nerves, and 1 would especrally emphasize those between the auricular branches of the ninti and 
tenth, and the seventh nerves, both within the Fallopian canal and externally on the postero-mesial surface of the auricle.

The nerve-supply of the Gasserian and upper cervical ganglia on the auricle has been carefully studied by a number of methods; the most satisfactory results have been obtained by a study of the field of anesthesia after surgical extirpation of the ganglion. Harvey Cushing, ${ }^{5}$ in particular, has made a most accurate and conclusive investigation of these auricular fields by this method. According to Cushing, the line of the posterior limit of the trigeminal field on the auricle takes the course shown in Figure 8 and described in the quotation below.

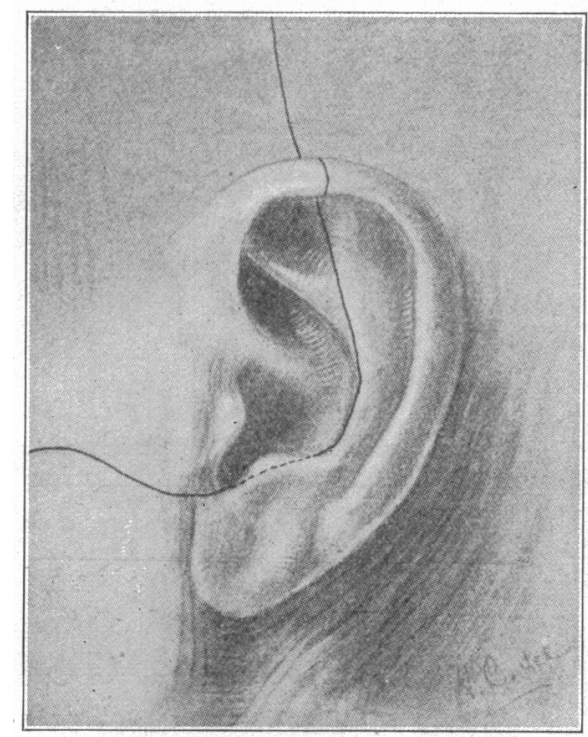

Fig. 9.-Outlines of the auricular portion of the cervical field delimiting the area of tactual anesthesia. (After Cushing.)

"It then drops to the anterior attachment of the pinna, around the edge of which it curves in a backward direction so as to include a small section of the ascending ridge of the helix, with the entire crus of the same; thence it disappears in the external auditory canal in the upper edge of the meatus; from this point the line passes into the canal along its upper wall as far as the tympanic membrane, which is included to a greater or less extent in the anesthetic area, returns along the lower and anterior wall of the canal to the lower edge of the tragus, where it once more reappears on the exposed cutaneous surface."

The line of the anterior limit of the cervical zone on the auricle, after extirpation of the second and third cervical ganglia (Fig. 9), "strikes the pinna at about

5. Cushing, H.: The Sensory Distribution of the Fifth Cranial Nerve, Bull. Johns Hopkins Hosp., 1904, xv, 213. 
its upper mid-portion, ascends over the edge of the helix to the outer face of the ear which is crossed behind the fossa triangularis to the antihelix; the ridge of this latter structure it follows passing around the posterior margin of the concha to the incisura intertragica, the line usually dipping in somewhat on the inner face of the antitragus; from the incisura intertragica, $5 \mathrm{~mm}$. or more below the point of emergence of the trigeminal line for touch, it passes out on to the cheek, usually in a forward and downward direction."

If the fields of the trigeminus and of the second and third cerrical ganglia are now brought together and adjusted on the auricle, there is found to exist an intervening area consisting of the concha, fossa of the antihelix, tip of the antitragus, and the posterior portion of the meatus, auditory canal and trmpanic meubrane. This small intervening area, I believe, contains the somatic or auricular representations of the geniculate, glossopharyngeal and vagal ganglia.

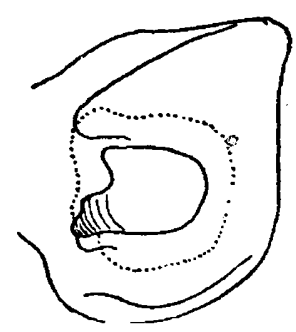

Fig. 10.-Within dotted lines lies the "completely delimited area of the auricular branch of the vagus" determined experimentally for the macaque. (Sherrington.)

Sherrington ${ }^{6}$ has succeeded in demonstrating the existence of a similar area in monkeys by the experimental method of "remaining esthesia." His description of this field is in part as follows (Fig. 10):

The field has been completely delimited in two experiments only; the operation required for revealing it is somewhat severe. Lying, as the small field does, wedged in between the large fields of the fifth eranial and the third cervical, and, as it were, imbedded in the anterior part of the field of the second cervical, it is, in order to isolate it, necessary to sever the fifth cranial at its origin, and also the highest thrce cervical nerves inside the vertebral canal. When this has been successfully accomplished, a patch of esthetic skin is easily demonstrable on the ear. It includes and immediately surrounds the external auditory meatus. Its shape and size, in the experiment carried out on it, were almost identical. It takes in practically the whole of the concha, the antitragus, part of the tragus and part of the antihelix; also part of the fossa of the antihelix. Its limits can be better reałized from the figure than from verbal description. The surface inside the external auditory meatus was sensitive in my experiments as far inward as could be tested with an ordinary probe.

6. Sherrington, C. S.: Experiments in Examination of the Peripheral Distribution of the Fibers of the Posterior Roots of Some Spinal Nerves, Phil. Tr. Royal Soc. of London, Series B, 1898, cxe, 64 . 
It then appears, that by both clinical and experimental methods, a cutaneous area may be demonstrated on the external ear, intercalated between the Gasserian and cervical zones, the innervation of which has been aseribed to the auricular branch of the ragus. In man, this area corresponds to the concha, a portion of the antihelix, the fossa of the antihelix, antitragus, incisura intertragica, and the posterior portion of the trmpanic membrane, external auditory canal, and meatus. In the macaque, it apparently includes as well the tragus, and the anterior portion of the tympanum and auditory canal.

\section{THE DISSECTYO METIIOD (SEXSORY NERVES OF THE AURICLE)}

Anatomists agree that the auricular branches of the fifth destined for the external ear, dip into the auditory canal along the anterior border of the external meatus, passing as far inward as the tympanic membrane and participating in its innervation. Anatomical authorities are at variance, however, as to the exact rôle played by the trigeminus in the innervation of the tympanic membrane. Testut states that the upper two-thirds of this membrane is supplied by the auricular branch of the ragus. Hasse, ${ }^{8}$ however, assigns the anterior two-thirds of the tympanic membrane to the fifth, and the posterior third to the vagus.

\section{THE AURICULAR BRAXCH OF THE VAGUS (NERVE OF ARTOLD)}

Opinions are also at rariance as to the distribution of this singular nerve on the auricle; it is generally supposed to innervate the posterior portion of the tympanum and the posterior wall of the auditory canal, as well as a strip on the posteromesial surface of the auricle, and the immediately adjacent mastoid region. Quain's ${ }^{9}$ description of its course and distribution is as follows:

The auricular branch (nerve of Arnold) arises from the ganglion of the root (ganglion jugulare); it receives the filament from the petrosal ganglion of the ninth; it then enters and traverses the substance of the temporal bone, crosses the aqueduct of Fallopius about $4 \mathrm{~mm}$. from the lower end, forming a communication with the facial, and finally emerges between the external auditory meatus and the mastoid process. It divides into two parts, one of which joins the posterior auricular nerve of the seventh, while the other is distributed to the skin on the back of the pinna and the lower and back parts of the auditory canal.

Because of the union of the auricular branches of the ninth and tenth nerres, it is impossible to separate their peripheral distribution on the external ear.

7. Testut, Les nerfs craniens; in Anatomie humaine, Ed. 5, 1905, iii, 86.

8. Hasse: Atlas der Hirn- und Rïckenmarks-Xerven., 1900.

9. Quain's Anatomy; The Cranial Nerves, Eil. 11, 1909, iii, Part 2, p. 31. 
The dissection mothod therefore shows that the fifth is concerned in the innervation of the anterior portions of the tympanic membrane, exter. nal auditory canal and meatus; and the ragus, in the imnerration of the posterior portion of the tympanic membrane and auditory canal, together with a strip on the posteromesial surface of the auricle. 'The exact boundaries of their respective distribution within the canal is still a matter of dispute.

This leaves the consha, tip of the antitragus, a portion of the antihelix, and the fossa of the antihelix still unaccounted for, and the innervation of this area $I$ believe to be related in part to the geniculate ganglion of the seventh.

\section{EMIBRYOLOGY}

Developmental studies in the human embryo and the lower forms of life have contributed very largely to our knowledge of the morphology of the cranial nerres, their origin and distribution. In the light of these investigations, the seventh, ninth and tenth nerves are to be regarded as branchial nerves, which in the lower vertebrate forms stand in immediate relation to their respective visceral clefts and arches. The seventh is the nerve of the first visceral cleft. From this cleft and its adjacent arches are developed the structures of the external ear, the tympanic membrane closing and separating it from the first visceral pouch. The anterior or mandibular arch lies within the area of the trigeminus, and gives rise to the tragus and the crura of the antihelix of the adult ear, which is in accord with Cushing's studies and the results of the dissection method (Fig. 11).

The posterior, or hyoid, arch is innerrated by the facial system. From this arch are developed the auricular tubercles of the antitragus, antithelix, and the lobule. As the concha auris and external auditory canal are similarly related to the first visceral cleft, they too may be regarded as falling in part within the area of innervation of the seventh nerve (Fig. 12).

The auricular branch of the vagus is considered by some embryologists to be a remnant of the so-called lateral line (ramus lateralis), and has been traced as far forward as the first visceral cleft, where, as we have seen, dissection method has shown it to be partly distributed (auditory canal).

Embryology, therefore, shows that the tragus and crura of the antihelix are situated within the area of the trigeminus; the antitragus, lobule, antihelix, concha, and part of the auditory canal, within the area of the facial. The auricular branch of the vagus may be traced anteriorly into the first visceral cleft. 
These various anatomical facts may be summarized as follows:

There exists on the auricle a cutaneous zone which is independent of the trigeminal and cervical innerration of this structure. This area is innervated by fibers arising from the geniculate ganglion of the scventh, the petrous ganglion of the ninth, and the jugular ganglion of the tenth. It appears probable from the dissection method that the auricular bianch of the ragus, which also includes the auricular branch of the glossopharyngeal, participates in the innerration of the posterior portion of the tympanum and auditory canal, together with a strip on the postcromesial surface of the auricle and adjacent mastoid.

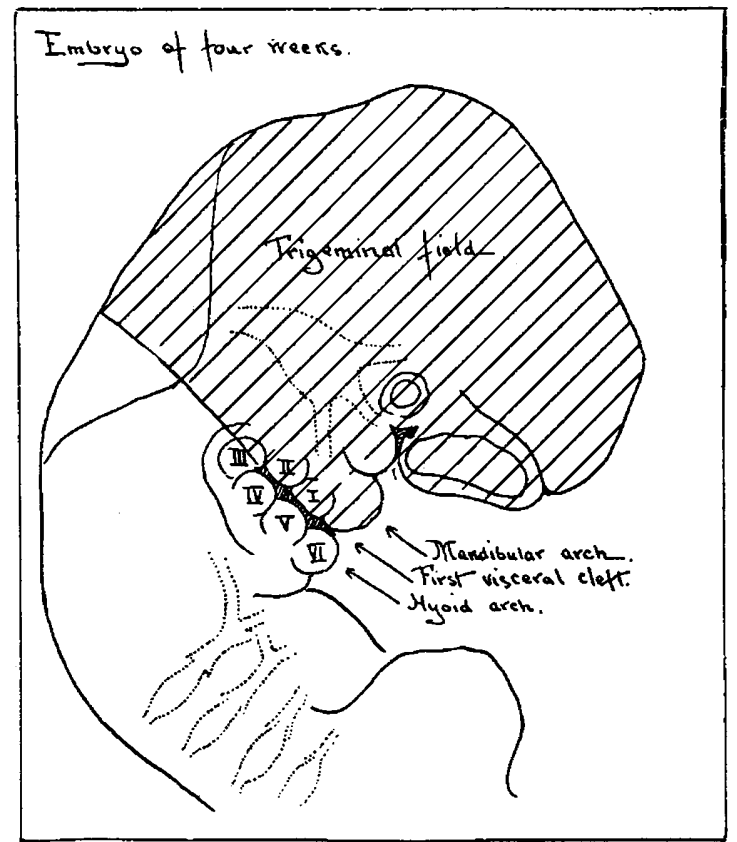

Fig. 11.- Relation of the auditory tubereles of the mandibular arch to the trigeminal field, in an embryo of four weeks. (After (ushing.)

It also appears probable that the concha, antihelix, fossa of the antihelix, antitragus, incisura intertragica, and a portion of the lobule are in part innerrated by the geniculate ganglion, the sensory fibers of which course in the trunk of the seventh, probably reaching the external surface of the auricle with the branches supplying the minute muscles of the external car. In this relation one must consider, howerer, the anastomoses which take place between the seventh, ninth and tenth nerres. 
This sensory inneration of the facial receives a further colvoboration from jts devclopmental relation to the first visceral cleft and the anricular tubercles of the posterior or hroid arch. I helieve, the pefore. that the ganglion of the serentl nerre has a representation on the external ear. between the zones of the Gasserian and cervial ganglia; also that the

A

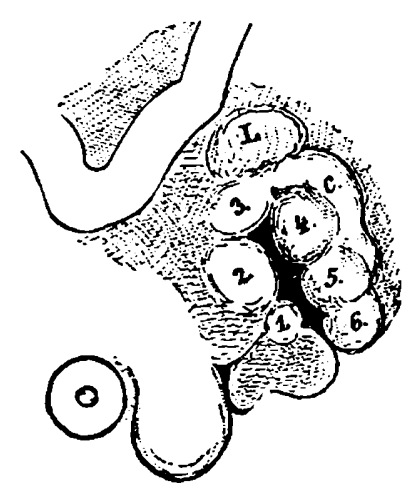

$\mathrm{C}$

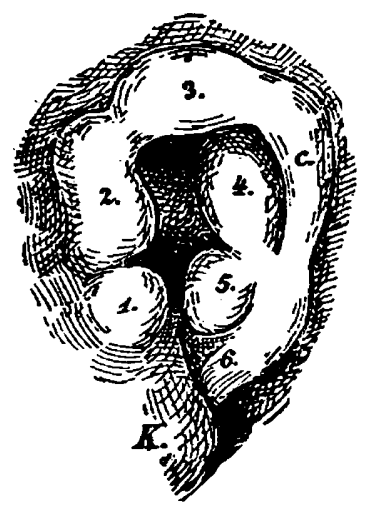

B

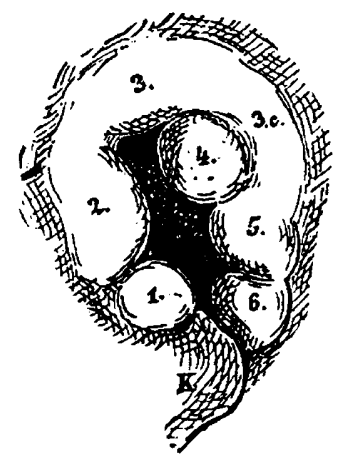

D

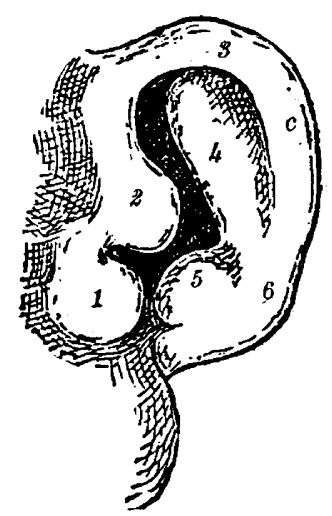

Fig. 12. - Sketches showing the development of the parts of the external ear from prominencess on the mandibular and hrod areles (His). Varionsly magnified. A, embryo at the end of the first month; B, emlryo of thirty-five days; $C$, embryo of thirty-eight ditys: D. embryo at the end of the second month. 1, tuberculum tragieum; 2 . tuhereulum anterins helicis: 3 . tuberculum intermedium helicis; $3 e$ ant $\theta$, calda helicis: t. tuberculum antilelicis: j. tubereulum antitragicum; 6, tubereulum lobulare; L, in $A$, aulitory resicle: $K$. lower jaw.

ganglia of the gloswoplaryoneal and ragus are represented in part on the posterior portion of the trimpanum and auditory camal, as well as on the posterior mesial surface of the auricle and adjacent mastoid region. 


\section{TIL: “FERPES ZOSTER" METILOD}

The herpes zoster method of determining the sensory representation of spinal ganglia has been used so successfully by Henry Hearl and his collaborators that I need not dwell on its many arlvantages as a means of ascertaining the sensory zones of small and obscure ganglia like those under consideration, which are also of the spinal type. It is rery evident that a study of those cases of true herpes zoster. in which the eruption is confined to the auricular area in question, would furnish evidence of fundamental importance in clearing up this subject. With this end in view, I have analyzed twenty-seren ases of true heres zoster oticus, in which the eruptive manifestations were limited to small areas on the external ar. 'These, I helieve, are dependent on herpetic inflammations (posterior poliomyelitis) in one or more of the three ganglia represented in this area; the geniculate, glossopharyngeal, and ragus. In five of these ases the resicles were localized, either on the trmpanic membrane alone or upon the posterior wall of the auditory canal. In four of the cases they were situated on the posteromesial surface of the auricle and adja(ent mastoid region. It will be observed that the localization of the resicles in both of these groups correspond in their distribution to the auricular branches of the jugular ganglion of the vagus. For reasons alıeady stated, it is probalsle that the ganglion of the ninth may also be roncerned in their production.

In eighteen of the cases the eruption was distributed in what I regard in part as the geniculate area on the external car: i. e.. the external meatus, concha, tragus, antitragus, antihelix, and fossa of the antihelix, and the upper portion of the external surface of the lobule. This representation of the geniculate on the cxternal ear is corroborated by the occasional presence of hrpesthesia in the region of the concha in cases of recent peripheral facial palsy. ${ }^{10}$

From the "herpes zoster" evidence, I believe that we are justified in drawing the following conclusions: True herpes zoster oticus is depen. dent on a posterior poliomyclitis of the geniculate, glossopharyngeal, or ragal ganglia. The ganglia of the tenth and the ganglia of the ninth are represented in part on the posterior portion of the tympanic membrane and auditory canal, as well as on the posteromesial surface of the auricle and adjacent mastoid region.

The zoster zone of the geniculate ganglion is represented on the external surface of the auricle, intercalated between the zone of the trigeminus in front and the cervical ganglia behind. From the relation

10. Hunt, J. Ramsay: The Sensory System of the Facial Nerve and Its Symptomatology, Jour. Nerv. and Ment. Dis., 1909. xxxvi, 321. 
which the facial bear's to the first visceral cleft (the auditory canal) it is very probable that the zone of the geniculate dips into the auditory canal as far forward as the tympanic membrane, in the same manner as do the auditory strips of the trigeminus and glossopharyngeal-vagus.

As I have already indicated, a considerable allowance must be made in these zones, as I have outlined them, for anatomical anomalies of rarious kinds, and for the normal physiological variation and overlap of sensory areas. Furthermore, these sensory areas are small and, like the minute muscles of the external ear, must be regarded as more or less vestigial in character. In other words, as remnants of sensory zones, which are gradually fading away under the overlap of larger and more important sensory systems.

\section{THE PARALYTIC COMPLICATIONS OF HERPES ZOSTER OTICUS}

In cases of herpes zoster oticus, facial paralysis and auditory symptoms may accompany or follow the eruption. The face on the affected side may be paralyzed without symptoms referable to the auditory nerve; auditory symptoms also may occur without facial palsy.

Among the twenty-seren cases of my series with herpes oticus, facial and auditory symptoms were both present in six cases. Facial palsy oscurred alone in six, and auditory symptoms in three cases. The facial paralysis was always complete, involving all three branches, while the auditory symptoms varied in intensity from hypacusis with tinnitus aurium to the severer manifestations of Ménière's syndrome. The general constitutional reaction was in the greater number of cases a very trivial one. In some, however, there was considerable prostration, accompanied by headache, rigidity of the neck, with nausea and vomiting. Nausea and vomiting were so severe and persistent in some instances, as to suggest a disturbance of the vagus nerve, which was further confirmed by the associated bradycardia.

This group is of such unusual clinical interest, that I append the abstracts of some very typical cases.

CaSE 10.-Herpes Zoster Oticus, with Vomiting and Bradycardia.-(Observation by Buys. ${ }^{11}$ ) A girl, aged 17. Onset with headache and vomiting. Headache very severe and accompanied by stiffness of the neck; frequent vomiting and photophobia. No fever, no delirium. Pulse was slow and irregular; on the fourth day, the pain subsided somewhat and settled in the mastoid region of the right side. Hearing was diminished and the auditory canal was tender on the introduction of the otoscope. The next day an eruption of herpes appeared on the antitragus and lobule of the right ear. The day following this a fresh crop of vesicles

11. Buys: Eruption herpétique du pavillon, Bull. Soc. belge d'otol., laryngol. et rhinol., 1898 . 
appeared on the internal face of the lobule and pinna. In the course of a few days the pain subsided and hearing was restored. All traces of the eruption disappeared in fifteen days.

Comment.-This case is noteworthy because of the distribution of the eruption in the zonal areas of the geniculate and vagal ganglia, and because of the associated bradycardia with frequent vomiting; suggesting a disturbance of the functions of the vagus.

The following observation by Mignon, ${ }^{12}$ is of interest, as the eruption corresponds to the auricular distribution of the vagus nerve. There was an associated deafness, but no symptoms of vagus irritation are recorded.

CASE 11.-Patient, a woman, onset January 3, with severe pains in the left ear, posterior surface of the auricle, and the mastoid region. Fever and malaise. Two days later tinnitus in the left ear and deafness, with herpetic vesicles situated on the outer third of the auditory canal. The pinna was congested, as was also the skin over the mastoid. The next day herpetic vesicles were noted on the mastoid and the postero-internal surface of the auricle. Tympanic membrane normal. The deafness on the left side was of the nervous type, accompanied by severe tinnitus. No nystagmus, no vomiting, no vertigo, no signs of facial palsy. In a fortnight the hearing had improved considerably and at the end of a month was entirely normal.

CASE 12.-Herpes Zoster Oticus uith Seventh Nerve Palsy, Auditory and Fagus Symptoms.- (Observation by Hammerschlag..13) Man, aged 25. On July 7, exposure to cold, while overheated. The next morning, a sore throat which increased during the day and continued for five days. On July 17, the soreness of the throat had disappeared, but vomiting set in and persisted during the day. The vomiting occurred without retching, and immediately after the ingestion of food. July 19 he was able to retain milk in small quantities. On this day there appeared sudden sharp pains in the right ear, radiating through the whole side of the head. At the same time there was a weakness of the right side of the face, and severe vertigo, aggravated by movements of the head. From this time the patient had to be assisted in walking, owing to the disturbances of equilibrium and a tendency to fall to the left. On July 20, vomiting again set in, and even the slightest nourishment was rejected. On July 25 the respiration was regular and deep, twenty to the minute; pulse frequency, 48. Laryngological and rhinological examinations were negative. July 27 , there is still vertigo and vomiting. Pupils are normal; nystagmus in the extreme position. Pain sense is diminished on right face in trigeminal area; corneal and conjunctival reflexes are diminished on the right also, the auditory canal reflex diminished on the right. Points of exit of the fifth nerve are tender. There is right facial palsy. Innervation of palate normal; taste sense is diminished on the right. Tear secretion is present. Pulse is 72 and regular. July 28 ; The left tympanum is normal; the right is concealed by dusting powder. In the auditory canal, especially at the entrance, there are several small scabs and in the cymba conchæ a small scar; these are the remains of an eruption of herpes zoster. The hearing is diminished on the right side and is of the nerve type. Acumeter; left side, 12 meters; right side, $75 \mathrm{~cm}$; bone conduction heard only on the left. Weber's test lateralizes to the left. Eye-grounds are normal. During the last few days, the above symptoms have diminished in intensity.

12. Mignon: Zona otique, Bull. de laryngol., otol., et rhinol., 1909, xii, 196.

13. Hammerschlag: Die rheumatische Affectionen der Gehörnerven., Arch. f. Ohrenh., 1901, lii, 7 . 
August 4: Acumeter on the right side, $1 \mathrm{~m} ., 30 \mathrm{~cm}$. Slight facial weakness is still apparent and the taste is still diminished on the right. Gait practically normal. Sensation of face slightly hypesthetic. The auditory canal reflex still diminished. There is tinnitus aurium; the right side of the face shows diminished faradic with normal galvanic responses.

Cuse 13.--Herpes Zoster Oticus with Facial Pulsy and Auditory symptoms.(Observation ly Ilammerschlag..4) Man, aged 32. On March 14, while the patient was walking in a snowstorm, right side of the face was exposed to severe cold. Five days later there were chills and on March 20 , onset with romiting and vertigo-objects rotating from right to left.

On the morning of the 20th, on awaking, patient had a headache and severe pains in the right ear, accompanied by roaring sounds. A weakness of the right side of the face was also apparent. The pain racliated to the forehead, eye and to the tectl of the upper and lower jaw. Sensation of the right side of the face was diminished. Mareh 22 , the tear secretion was absent on the right side; there was a right facial palsy, and nystagmus followed lateral movements. In the fossa of the helix, on the lobe of the ar and on the tragus, there was an eruption of herpes zoster. Thre were no vesicles within the auditory canal. Tearing was diminished on the right: the watch tick at $35 \mathrm{~cm}$., not heard on the mastoid. There was considerable disturbance of the equilibrium both in standing and walking. The gums, above and below on the right side, were a little swollen. The conjunctival reflex was absent on the right. Sensation of taste was lost on the right.

March 31, face was improved. Tearing on the right was $40 \mathrm{~cm}$. by watch; bone conduction for wateh, still absent.

April 1, there was still vortigo and tinnitus: tear secretion normal.

April 3, tinnitus in the right, and occasional shooting pains. J3one conduction had improved.

April 5, taste improved.

April 25, patient complained of cold sensation in the head and constant tinnitus in the ear. The upper branch of the seventl showed improvement, none of the lower branch. The gait was much better. The bone conduction on the right was absent; the wateh was heard only on contact; for several days past there had been diplacusis on the right side, and a disagrecable sensation was produced by musical tones.

CASE 14.-Observation by Newmann: A man, aged 44. Onset with pains in the right ear and occipital region, accompanied by vomiting and objective vertigo. Two days later, herpetic resicles appeared in the external auditory canal. The next day there was facial palsy; the pulse was slow, the temperature $38.8 \mathrm{C}$. The auricle was red on its superior portion and the skin was thickened. Functional tests showed complete deafness to fork and voice in the right ear. The vestibular apparatus was inexcitable. At the end of three weeks, the vestibular apparatus still was inexcitable, and absolute deafness with facial palsy persisted. The case was presented as one of rheumatismal cerebral polyneuritis.

\section{THE ZOSTER ZOXES OF THE GLLSSOPH.ARYGEAL ATD TAGAL GAMGLIA WITHIX THE BUCCAL CATITY}

The glossopharyngeal nerve has two ganglia situated on its root; the ganglion petrosum (Andersch), and a small accessory ganglion, the ganglion of Ehrenritter; both are homologues of the spinal ganglia, are

14. Hammersehlag: Bejtrag zur Casuistik der multiplen Hirnnerven-Erkrankungen, Arch. f. Ohrenh., 1898, xlv, 1. 
composed of unipolar cells, and therefore belong to the ganglionic chain which is liable to the specific inflammation of zona (Fig. 13). These ganglia have a sensory representation on the auricle, and also an intraoral zone, situated on the postero-lateral surface of the tongue, the pillars of the fauces, tonsil, and the adjacent pharyngeal region.

The pneumogastric nerve has also two root ganglia; the ganglion jugulare and the ganglion plexiforme (Fig. 13). The cells of these ganglia are also of the unipolar or spinal type. The plexiform ganglion is situated extracranially, and is peculiar in that it is composed of a series of small scattered groups of cells which produce an elongated swelling of the nerve trunk, about $15 \mathrm{~mm}$. in extent. This plexiform arrangement is caused by the entrance into the trunk of the vagus, of the inter-

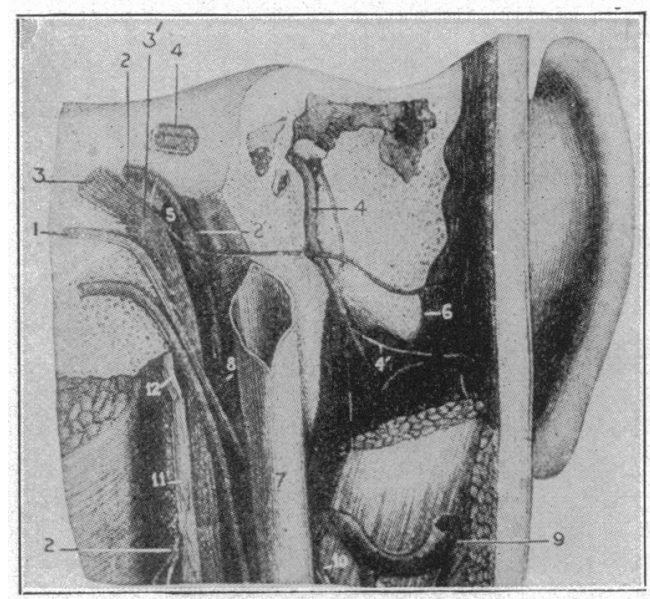

Fig. 13. - The ganglia of the ninth and tenth nerves and their auricular branches: (1) spinal accessory nerve; (2) glossopharyngeal nerve ; $\left(2^{\prime}\right)$ ganglion of Anderseh; (3) vagus nerve; (3') ganglion jugulare; (4) facial (4') auricular branch of facial; (5) auricular branch of vagus; (6) anastomosis between the auricular branches of the facial and vagus nerves (Testut's Anatomy.)

nal branches of the accessorius nerre, sometimes called the external or motor root of the vagus. It is important to note that these motor fibers of the accessory nerve destined for the muscles of the larynx, enter the vagus below the jugular ganglion, as a descending series of small branches. This morphological distribution may explain the apparent absence of laryngeal palsies in posterior poliomyelitis of the ragal ganglia.

In addition to an auricular representation, on the tympanum, auditory canal, and posteromesial surface of the auricle, these ganglia hare also 
an intra-oral zone situated on the root of the tongue, the structures at the entrance to the larynx, and the adjacent pharyngeal region (Fig. 14).

It may be remarked that these respective sensory areas of the glossopharyngeal and vagus nerves within the mouth carity are by no means definitely determined, and there is also cvery reason to believe that a considerable variation and overlapping exists.

In discussing the zoster zones of the auricle, I stated that a separation of the glossopharyngeal and vagus representations is impossible, as the

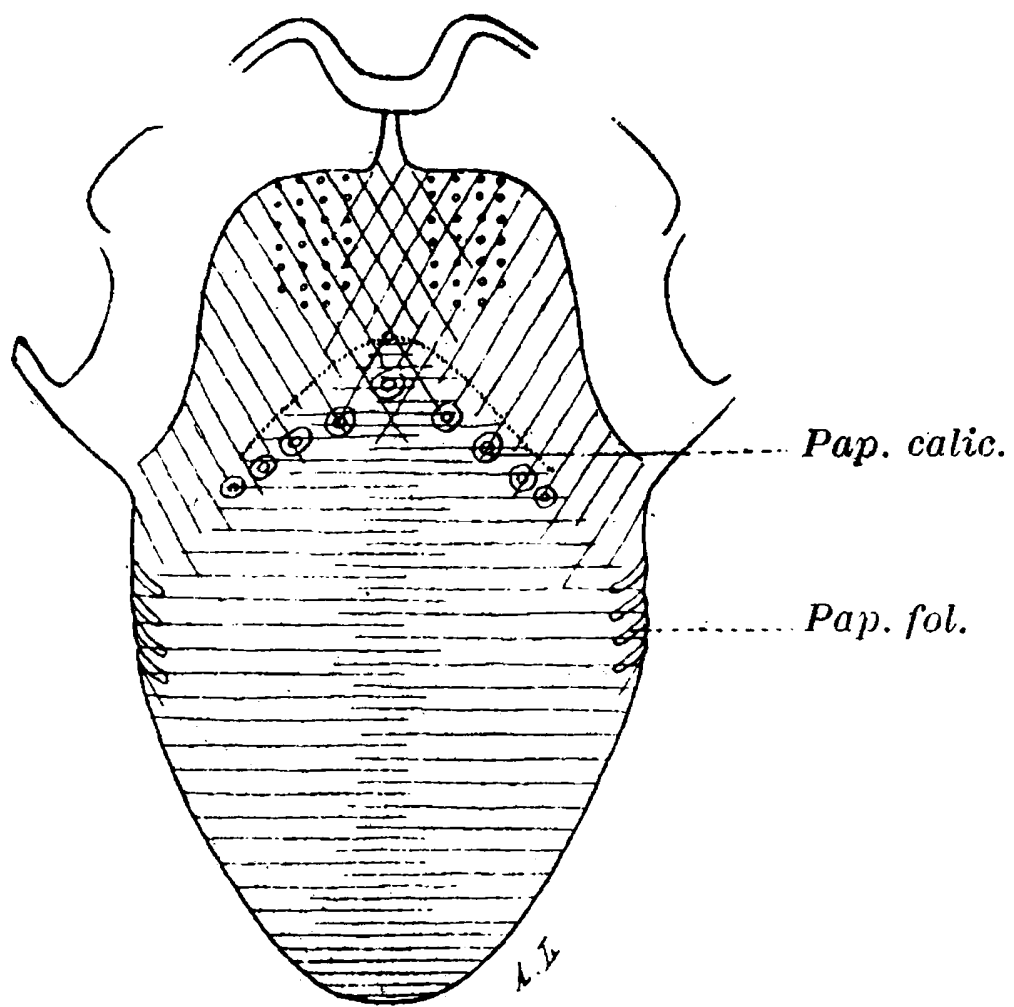

Fig. 14.-Sensory innervation of the tongue (after Zander). The lingual distribution is indicated by transverse lines, the glossopharyngeal by oblique lines and that of the pneumogastric by dots.

auricular branch of the ninth joins the auricular lranch of the tenth soon after leaving the ganglia. Their respective cutaneous destinations are therefore unknown and must be considered together.

In the posterior recesses of the buccal carity, where these ganglia are also represented, this is not the case, and the "dissection method" gives 
a very fair idea of their respective mucous membrane distributions. An exception to this is in the upper pharynx, where the rarious pharyngeal branches are lost in the mazes of the pharyngeal plexus.

The glossopharyngeal nerve, according to the best anatomical authorities, sends filaments to the mucous membrane covering the posterior margin of the soft palate, the anterior and posterior pillars of the pharynx, the tonsil, the posterolateral surface of the base of the tongne; also to the pharyngeal plexus.

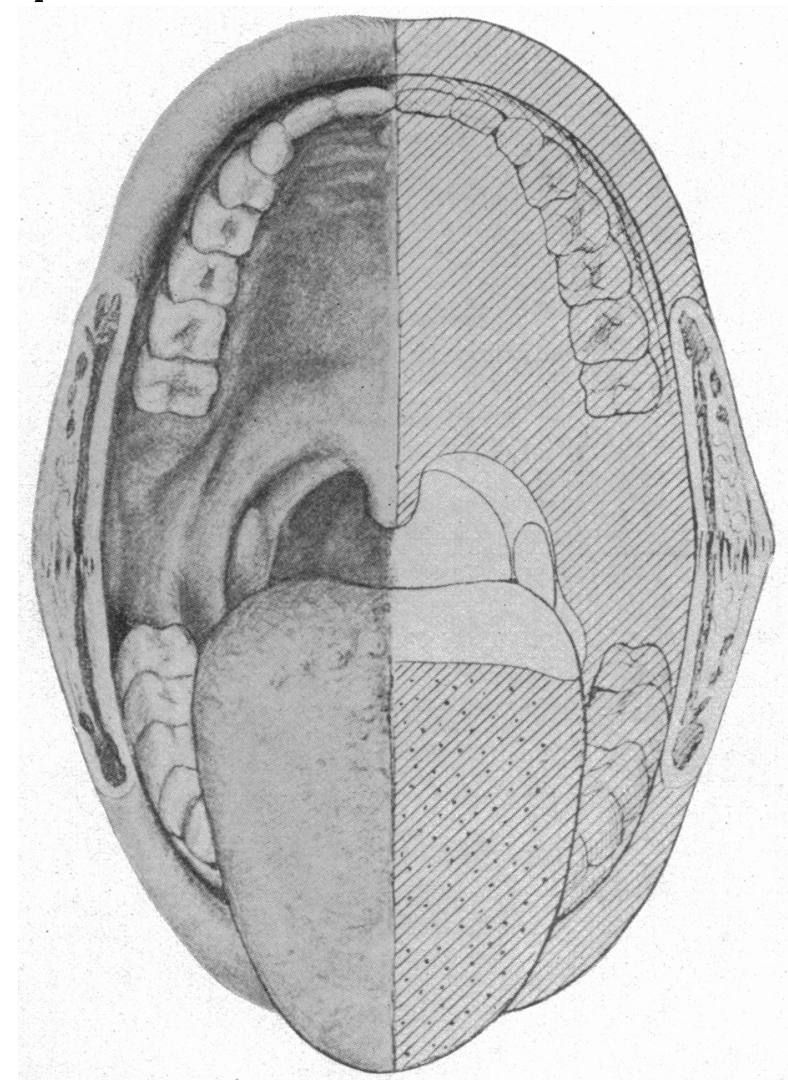

Fig. 15.-Posterior limits of the intrabuccal field of the trigeminus, after extirpation of the Gasserian ganglion. (Harvey Cushing.)

From the vagus nerve sensory filaments pass to the mucous membrane covering the epiglottis, arytenoid eminences, and the aryteno-epiglottidean folds; also to a wedge-shaped area at the base of the tongue, situated immediately in front of the epiglottis (Fig. 14). The vagus also sends branches to the pharyngeal plexus. 
The intra-oral zone of the glossopharyngeal is therefore intercalated between the trigeminus in front and the vagus behind, and corresponds roughly to a semilunar strip passing from the posterior margin of the soft palate orer the pillars of the fauces, the tonsils, and the posterolateral surface of the tongue, including also an unknown area of the upper pharynx (Figs. 14 and 15).

The intra-oral zone of the vagus is situated more posteriorly and corresponds to a small wedge-shaped strip at the base of the tongue, which is continued over the epiglottis, aryteno-cpiglottidean folds and the arytenoids, including also an unknown representation in the upper pharynx.

It will be observed that both the ninth and tenth nerves give off branches which unite with the sympathetic to form the pharyngeal plexus. Their respective distributions in this region are unknown and must be considered together.

\section{ILIRPES ZOSTER PHARYNGIS AND IIERPES ZOSTER LARYNGIS}

Laryngologists have recognized for many years the occurrence of herpes zoster on the pharynx and on the larynx. In the rather voluminons literature of this subject, these cases are rariously described as herpes pharyngis, herpes gutteralis, angina herpetica, and the herpes laryngis.

The cases may be sharply divided into two distinct groups, one a pseudoherpes, the other a true herpes or zona. In the latter group of cases, the eruption is unilateral and corresponds to a lefinite neural distribution; while in pseudo-herpes, the eruption is not a zona in the true sense of that term, the appearance of an eruption being produced by closure of the glandular ducts with retention of their secretion.

In such cases the eruption is bilateral and disseminater, and is commonly distributed orer the soft palate, urula, pharynx, epiglottis, arytenoid cartilages, and aryteno-epiglotticlean folds. There is also usually a considerable degree of inflammation, with edema of the mucous membrane, and the dysphagia and dyspnea are often extreme.

The pseudo-herpes I have entirely excluded, and will confine my remarks to the pure cases of unilateral herpes of the pharynx and larynx. These cases compared with the other varieties are infrequent, but I belicre less so than might be inferred from a perusal of the literature. The constitutional symptoms are often very slight and the eruption particularly eranescent on mucous surfaces, the resicles breaking down rapidly under the heat and moisture of the month, learing small whitish or yellowish flecks rery unlike our usual conception of an herpetic eruption. For this reason they may readily bo overlooked, or their real nature not detected. 
Another source of error is the small area of the zostcr zones and their inaccessibility. I regard it as very probable that many acute milateral palsies of the face, palate, and even the laryns, coming on after exposure to cold, and called "rheumatic." belong in this group, the paralytic symptoms following herpetic inflammation of their respective ganglia. This is probably also true of similar cases of obscure toxic origin.

\section{THE COMPLICATIONS OF HERPES ZOSTER PHARYNGIS AND LARYNGIS}

\section{THE PARALTTIC COMPLICATIONS OF ILERPES ZOSTER PIARYAGIS}

Most systematic writers, in their descrjptions of herpes zoster pharyngis, mention paralysis of the palate as an occasional complication. Eichhorst ${ }^{15}$ states that in herpes pharyngis with unilateral eruption, patients often complain of a very bad taste sensation in the affected region; and in one case he observed paralysis of the palate. In another case, the eruption had a unilateral distribution on the posterior surface of the urula, and was risible only with the laryngoscope. 1)r. Isadore Abrahamson ${ }^{16}$ saw in Oppenheim's clinie in Berlin, a case of unilateral herpes zoster pharyngis the eruption situated on the tonsil and posterior margin of the soft palate, in which there was an associated facial paralysis on the corresponding side.

In two of my cases of herpes oticus with facial palsy, there was an associated paralysis of the soft palate on the affected side. It scems to me probable that such palatal complication may be due to an inflammatory reaction in the glossopharyngeal or ragal ganglia, causing this slight defect in the innervation. Should this be verified in a sufficient number of cases, it may throw an important side-light on that much-mooted question of the involvement of the soft palate in Bell's palsy.

Case 15.-Herpes Zoster Pharymgis with Fucial Palsy and Paresis of the Soft Palate-(Personal observation.) A man, aged 23; tailor, no venereal history, excessive cigarette smoker for some years. Onset Monday, Jan. 10, 1910, with pain in the left side of the throat. For one week previously he had not felt well, had headaches, chilly sensations and malaise. The pain and soreness in the left side of the throat continued with increasing severity on Tuesday, Wednesday and Thursday of the same week. On Sunday, January 16 , there developed a left facial palsy; at the same time there was considerable pain in the left ear and mastoid region, no auditory symptoms, no nausea or vomiting.

On examination, January 17 , at the Cornell Seurological Clinic, the patient complained of great soreness of the throat and pain chiefly on the left side, with

15. Eichhorst, H.: Specielle Pathologie und Therapie (Herpes Pharyngis), 1897 , iv, 268 .

16. Persomal communication. 
difficulty of deglutition; also sharp pains in the left ear and mastoid region, radiating to the iemple and the occiput. There was complete left facial palsy; hearing normal; no signs of herpes about the face, neck, auricle or auditory canal.

Laryngoscopic examination(Cornell Clinic) showed that the uvula was enormously swollen and edematous, and could be inspected only by being brought forward onto the dorsal surface of the tongue, by means of a probe. A few herpetic vesicles were visible on its left side, as well as along the left anterior pillar of the fauces. The tonsils were not enlarged and not inflamed. The posterior pharynx was congested. The entrance to the larynx was normal and no herpetic vesicles were demonstrable. A swollen and tender gland was palpable, beneath the left angle of the jaw.

Jan. 18, 1910: Laryngoscopic examination by Professor Newcomb. The edema and swelling of the uvula still great but diminishing. In the left faucial region, along the anterior pillar, small round erosions were visible. Larynx was normal, and free from herpes or erosions.

January 19: Pain was still severe in the left side of the throat, ear and mastoid region. Otological examination was negative. The innervation of the soft palate appeared normal. Tear-secretion was increased in the left side (oil of mustard). Pulse-rate was 90 ; heart-sounds normal. Sensation of the face and ear were normal.

January 20: Constant pain in the left ear and mastoid. Slight tinnitus, not constant. Hearing normal. Left facial palsy was complete.

January 21: Sense of taste was preserved on the left side of the tongue in both the trigeminal and glossopharyngeal distribution; it was somewhat delayed in the trigeminal area, however. Swelling of the uvula was diminishing. Innervation of the palate appeared normal.

January 24: Inspection of the soft palate revealed a definite droop of the left palatal arch, and on innervation a definite defect was noted on the left; the palate was lifted up and toward the right. A few small erosions were still present along the left anterior pillar and adjacent tonsillar region, and there was a burning sensation in this region after taking food. Sensation of the palate was equal on the two sides, and the palatal reflexes were present. The sensations of touch and taste in the glossopharyngeal distribution of the tongue were normal.

February 4: Slight power was returning to the left side of the face. Still pain in the left ear; pulse was 98 and regular.

February 7: Pains in left ear, radiating to mastoid, occiput and temple. Past few days patient had experienced a sensitiveness to loud sounds in the left ear. Slight difficulty in deglutition. Paresis of the left side of the soft palate still present; the raphe deviated from the median line toward the right. Facial palsy was improving. Pulse-rate 102.

February 16: Pains in the ear still present; pulse 100.

February 18: Pulse 106.

March 4: Pulse 78. Weakness of the left side of palate still present, but improving. Innervation of left face was much better.

March 20: Patient was free from pain. Only slight defect in the innervation of the left side of palate was demonstrable. Movements of the face on the left side practically normal. Pulse 78 . Patient discharged and returned to his occupation. The treatment consisted solely of analgesics for the relief of pain and galvanism.

comment.-This case is of unusual interest because of the coexistence of facial palsy, paresis of the soft palate and herpes pharyngis. The herpetic eruption was distributed on the left side of the uvula and along the anterior pillar of the fauces, $i$.e., within the intra-oral representation of the glossopharyngeal ganglia. The facial palsy appeared on the sixth day and the defect in the innervation of the soft palate at the end of the second week. The pains were of unusual severity and 
persisted for a considerable time. They were localized in the left side of the throat and the left ear. The pulse-rate was high during the active period of the disease. There was no hiccough, nausea or vomiting. The patient had indulged excessively in the use of cigarettes for a number of years, so that the tachycardia may have had this etiology. I do not believe, however, that involvement of the pneumogastric can be entirely excluded. I would interpret the case as one of posterior poliomyelitis involving the glossopharyngeal and geniculate ganglion.*

In the following case, recorded by Ravnaud, ${ }^{17}$ there were associated herpes pharyngis, oticus, and facialis, with facial palsy, deafness, and abducens paralysis.

CASE 16.-A woman, aged 52; sudden onset May 2, 1875, with fever, and angina. On May 6 ; still fever, deglutition painful and difficust. Examination of the throat revealed an herpetic ermption limited to the left half the soft palate and the anterior pillar of the same side. On May 7 , several plaques of vesicles appeared on the left auricle, also a few vesicles on the left side of the face. Other vesicles were situated on the concha and in the auditory canal. On May 8 there was a left facial palsy with hemianesthesia of the left side of the face, also a small vesicle on the conjunctiva just above the cornea. There was also a distinct paralysis of the left externai rectus, and absolute deafness on the left side. From this time the symptoms remained stationary, but later the abducens palsy disappeared and sensation returned to the left side of the face. The herpes disappeared in twelve days, but the facial palsy persisted with disappearance of the electromuscular contractility.

Comment.-This is the only case among the eighty-seven of my series, in which mention is made of an ocular palsy in combination with facial paralysis or acoustic symptoms.

CASs 17.-Observation by Chauveau. ${ }^{18}$ A woman, aged 42. Sudden onset with fever, headache, sore throat and moderate dysphagia. A few hours later severe lancinating pains with tinnitus aurium in the left ear. Examination showed an herpetic eruption on the left tonsil, left side of the palate and uvula; none on the larynx. The auricle and auditory canal were free from eruption; but two vesicles were seen situated on the posterior part of the tympanic membrane. There was also a herpes labialis.

Comment.-In this case the eruption in the ear and throat is situated within the somatic and splanclinic zones of the glossopharyngeal ganglia.

* A few days ago I saw a case of Herpes Zoster Oticus and Pharyngis, with Facial Palsy, Hypoacousis, and Bradycardia, through the courtesy of Dr. Charles H. Peck. The eruption was distributed in the external auditory canal, the concha, antihelix, and the fossa of the antihelix of the right ear. (Tympanum free.) In addition there were herpetic resicles and erosions limited to the right side of the soft palate. The posterior half of the dorsum of the tongue on the right side was also red and swollen; innervation of palate normal. Sensation was diminished on the entire right side of the face, head and neck. Right corneal reflex was absent. Herpetic pains were severe. Diagnosis: Posterior poliomyelitis of the geniculate and glossopharyngeal ganglia.

17. Observation by Raynaud: Cited by Desirat; Complications du Zona, Thèse de Bordeaux, 1903, p. 20.

18. Chauveau, C.: Herpès du tympan avec un herpès guttural et labial, Ann. d. mal. de l'oreille, 1901, xxvii, 15 l. 
CASk 18.-Observation by Achard and castaigne. ${ }^{19}$ A man, aged 5l. Onset with pains followed by erythema of the left side of the face with an eruption of herpes yoster in all three branches of the left trigeminus, including its mucous membrane innervation. In addition, herpetic vesieles were present on the left posterior pillar of the pharynx and left tonsil. On depressing the tongue, vesicles were also evident on the left side of the pharyngeal vault. There was no dysphagia and the eruption on the mucous membrane caused no pain, and was not perceived by the patient.

Comment.-This case is of interest because of the involvement of two ganglia, the Gasserian and the glossopharyngeal; also as showing that true intra-aural herpes zoster may cause no especial pain or discomfort to the patient and therefore may be readily overlooked.

CAss 19.-Observation by Haviland Hall." A man, aged 41. Onset Dee. 27, 1906, with sore throat and dysphagia, especially on the right side; the right tonsil and pillar of the fauces appeared red and swollen.

Decomber 29: Still pain in the throat, extending up into the right ear; the right side of the throat was red and swollen, and there were two or three yellow spots on the tonsil and posterior pillars of the fauces. Temperature, 100.47.

December 3I: There was hoarseness and acute pain in the throat, shooting into the ear and entirely preventing sleep. There was now a typical herpetic eruption on the right side of the soft and hard palate, extending to within an inch of the teeth, and sharply limited on the inner side, by the median raphe of the palate. The larynx was normal.

January 1: Earache worse and a group of vesicles appeared on the right edge of the tongue, extending from the pillar of the fauces to within one and a half inches of its tip.

January 2: Patient still suffering much pain and three or four vesicles had made their appearance in the concha and below the helix of the right ear.

January 3: The throat was easier and a few vesicles appeared on the right parietal and temporal region.

January 6: There was general improvement, but the patient was still unable to take solid food.

January 8: An attack of liccongh and vomiting. The patient suffered from complete anorexia.

January 9: Hiceough was very troublesome and there were only short intervals of relief.

January 10: The hiccough was very severe and threatened to suffocate the patient; the paroxysms came on very rapidly with only about four or five seconds' interval. One attack lasted three and a half hours.

January 11: The hiccough ceased and frequent retching supervened.

January 14: Retehing and vomiting had gradually subsided and on Jannary 15 solid food wis taken.

January 26: Patient was extremely prostrated and the throat was still painful with occasional stabs of pain through the right ear.

Comment.-This case is of unusual interest because of the combined aluricular and intra-aural herpes, corresponding to the zones of the genieulate and glossopharyngeal ganglia, but more especially because of the severe pneumogastric symptoms, anorexia, retehing, romiting and hiccough. It will be observed that a period

19. Achard and Castaigne: Zona céphalique, Gaz. helud. de méd. et de elin., 1897 , new series, ii, $117 \%$.

20. Hall, F. de H.: Herpes of Mucous Membrane and Skin., Brit. Med. Jour., $1897, \mathrm{i}, 848$. 
of one weck elapsed between the outbreak of the eruption and the appearance of the pneumogastric symptoms. This interval of quiescence scparating the appearance of the eruption from the neural complications is of frequent occurrence in cases of geniculate inllammation with facial palsy.

\section{IELRPES LARYYGTS AND ITS COMPLICATIONS}

Posterior poliomyelitis of the root ganglia of the pneumogastric nerve is characterized by an eruption of herpes zoster in their auricular and intra-aural zones, and jn some cases by the occurrence of neural complications, such as bradycardia, nausea, romiting and hiccough. These symptoms are due to involvement of the pneumogastric fibers, passing through the inflamed ganglia.

Casl: 20.-Herpe's Zoster Laryngis.-(Observation by Scheff. ${ }^{21}$ ) A man, aged 61. Onset July 28, with pain in the throat and hoarseness following exposure to cold; there was fever and difficulty in deglutition. Laryngological examination shows redness and swelling of the right arytenoid cartilage, right aryteno-epiglottidean fold and the right side of the epiglot tis to the middle line with typical herpetic vesicles. The left side of the larynx was normal, as were also the rocal cords, base of the tongue and fossa pyriformis. On July 30 and 31 , pain and hoarseness continued with dyspnea and coughing. Examination showed the left side of the larynx still normal; the pharynx was normal but the wrula on its free end is somewhat edematous.

CASE 21.-Herpcs Laryngis.-(Observed by Stepanow:-2) A man, aged 48, entered the hospital on April 7 for congh, difficulty and pain in swallowing. The onset had occurred on April 1 with stabling pains in the neck.

April 8: Laryngoscopic examination. The left arytenoid cartilage was swollen and reddened on its inner surface, as was also the left half of the epiglottis on its posterior aspect, on which were situated three small grayish-white flecks; no other herpes visible.

April 14: Patient discharged cured.

(Ase 22.-Herpes Zoster Laryngis with Hiccough.-(Observation by Boulai."3) A man, aged 50. Sudden onset, Feloruary 29, with fever, headache, loss of appetite, general malaise and a sensation of discomfort in the throat. The general symptoms subsided, but the discomfort, leat. and irritation in the throat continued. It felt as if a foreign body were lodged behind the tongue, which the patient was unable to swallow; this was not a painful sensation but a perpetual discomfort and was accompanied by jncreascd salivation and frequent movements of deglutition. This had made its appearance on the second day of the disease and was preceded twelve hours by a persistent and distressing hiccough, occurring erery minute or half minute. This fyequency was maintained until the fifth day of the disease. At no time was there difficulty with breathing or articulation; the voice was a little husky.

Iarch 5: Laryngoscopic examination: The rhinopharynx was quite normal; the epiglottis is a uniform carmin red, but not edematous and was free from herpes on its anterior and superior surface. On its posterior aspect and solely on the left side there were six small grayish-white spots which were isolated and regularly

21. Scheff, G.: IIerpes Laryngis, Wien. med. Ztschr., 1881, xxvi, 475.

22. Stepanow, 1. M.: Herpes Jaryngis, Monatschr. f. Ohrenh., 1885, xix, 237.

23. Boulai: Herpes zostériforme, Arch, internat. de larrngol., 1904, xviii, 149. 
round. The left arytenoid was slightly infiltrated, and presented four small grayish flecks, which were a little larger than those on the left posterior surface of the epiglottis. The vocal cords were slightly reddened.

Mareh 9: The hiccough ceased and on March 10 the larynx had recovered its normal aspect. No vesicles were observed elsewhere.

\section{HERPES ZOSTER OF THE TONGUE WITH FACIAL PALSY}

Unilateral eruptions of herpetic resicles on the tongue, in the distribution of the chorda tympani nerre, are occasionally observed in cases of peripheral facial palsy. In some of the observations the eruption preceded the paralysis, in others it appeared subsequently. In the latter group it is probable that the herpetic manifestations are secondary or neuritic in origin; in the former group, a primary lesion of the geniculate ganglion itself is not improbable. The question then naturally arises whether the geniculate has a splanchnic innervation within the buccal cavity in addition to its somatic representation on the external ear.

\section{ANATOMIC CONSIDERATIONS}

It is well known that the chorda tympani supplies the anterior twothirds of the tongue with the sense of taste; its fiber's springing from the cells of the geniculate ganglion. It has also been shown that, in some (ases of facial palsy, the general sensibility of this region may also be obtunded, a fact long ago pointed out by Bernhardt. 'L'his would suggest that the chorda conveys some fibers of general sensation, as well as those subserving the spccial function of taste. Cushing's studies of the trigeminal field have shown that a crude sort of conmon sensation may persist on the anterior two-thirds of the tongue, after the Gasserian ganglion has been extirpated. This is further proof of the existence of such fibers. It is also worthy of mention in this connection, that the lingual branch of the seventh, which innervates the styloglossus and palatoglossus muscles at the base of the tongue, sends mucous filaments to the anterior pillars of the fauces and adjacent region. While it is true that this lingual branch has an anastomosis with the glossopharyngeal nerve, there is no proof that these mucous filaments are not part of the sensory facial system springing from the cells of the geniculate ganglion. The geniculate may therefore have a restigial intra-oral sensory representation in addition to its taste function, as have the glossopharyngeal and vagus nerves; and that all three branchial nerves, the seventh, ninth and tenth are represented both in the mouth cavity and on the external ear.

In the lower vertebrate the intra-oral representations of these nerves are extensive and important, but in the course of phylogenetic development are being replaced by the overlap and growth of the trigeminus. 


\section{CASES OF HERPES ZOSTER OF THE TONGLE WITH FACIAL PALSY}

CAsE 23.-(Observation by Dr. Jojn J. MacPhee of New York, unpublished.) A man, aged 45. Exposure to cold followed by severe pain behind the left ear. This was accompanied by burning sensation on the left side of the throat and tongue. The pains were very severe and the patient was forced to remain indoors for several days, requiring liberal doses of codein. Later, there developed a left facial palsy; no disturbance of learing. The sense of taste was lost on the anterior two-thirds of the tongue on the affected side. Herpetic vesicles and erosions were present within this area; no vesicles were visible on the left side of the throat, although a distinct sensation of burning had been present in this region, similar in character to that which was felt on the side of the tongue. No herpes in the ear or on the face. Later, partial reactions of degeneration were present on the left side of the face. The ear pains were of unusual severity and persistence.

CASE 24.- (Observation by Siegheim. ${ }^{24}$ ) A man, aged 72. Herpetic vesicles appeared on and behind the lobe of the right ear. A few days later a fresh crop of vesicles made their appearance on the right side of the tongue and hard palate. Eight days after the eruption, the right side of the face became paralyzed.

CASE 25.-(Observation by Bernack. ${ }^{25}$ ) Pains in the right ear for eight days followed by a right facial paralysis; with the palsy there appeared an eruption of herpes zoster on the anterior two-thirds of the tongue; sensations of tongue and taste were normal.

CASE 26.-(Observation by Eichhorst. ${ }^{26}$ ) Onset Dec. 12, 1906, after exposure to cold, followed by pains in the right side of the face and neck. On the third day a right facial paralysis appeared and four days after the palsy, a herpetic eruption appeared on the lower half of the right auricle, in the external auditory canal, and on the right side of the tongue, the uvula and hard palate. Hearing normal; taste preserved; uvula not paretic.

CASE 27.-(Observation by Remak..$^{-2}$ ) A man, aged 26. Onset Oct. 22, 1884, with pains in the right ear, followed on October 26 by a right facial paralysis. On Oetober 29, an eruption of herpes appeared on the right border of the tongue, in its anterior two-thirds; taste undisturbed; palate innervation normal. From November 10 to December 15, there was an excessive irritability of the auditory mechanism to sounds. Right face showed reactions of degeneration.

\section{\%. THE POSTERIOR POLIOMYELITIS OF THE AUDITORY GANGLIA}

The peripheral ganglia of the anditory nerve are homologues of the posterior spinal ganglia. They take their origin from the neural ridge as the ganglion acusticum, and in common with other ganglia having this derivation, manifest a susceptibility to the specific inflammations of

24. Siegheim: Herpes zoster im Gebiete des Nervus facialis dexter, Monatschr. f. prakt. Dermat., 1895, xx, 396 .

25. Bernack: Le paralysie faciale: cited by Despaigne, Thèse de Paris, 1888.

26. Eichhorst, H.: Herpes zoster und Facialislähmung, Contralbl. f. inn. Med., 1897 , xviii, 425.

27. Remak, E.: Zur Pathogenese des peripherischen Facialparalyse gelegentlich complic. Herpes Zoster, Centralbl. f. Nervenheilk., 1885, viii, 145. 
herpes zoster ( $\mathrm{Fig} .16$ ). The cells composing the acoustic ganglia retain. howerer, their primitive bipolar character, althougl recent inrestigations have shown that a few unipolar cells are demonstrable in man (Tan Gehuchten²s).

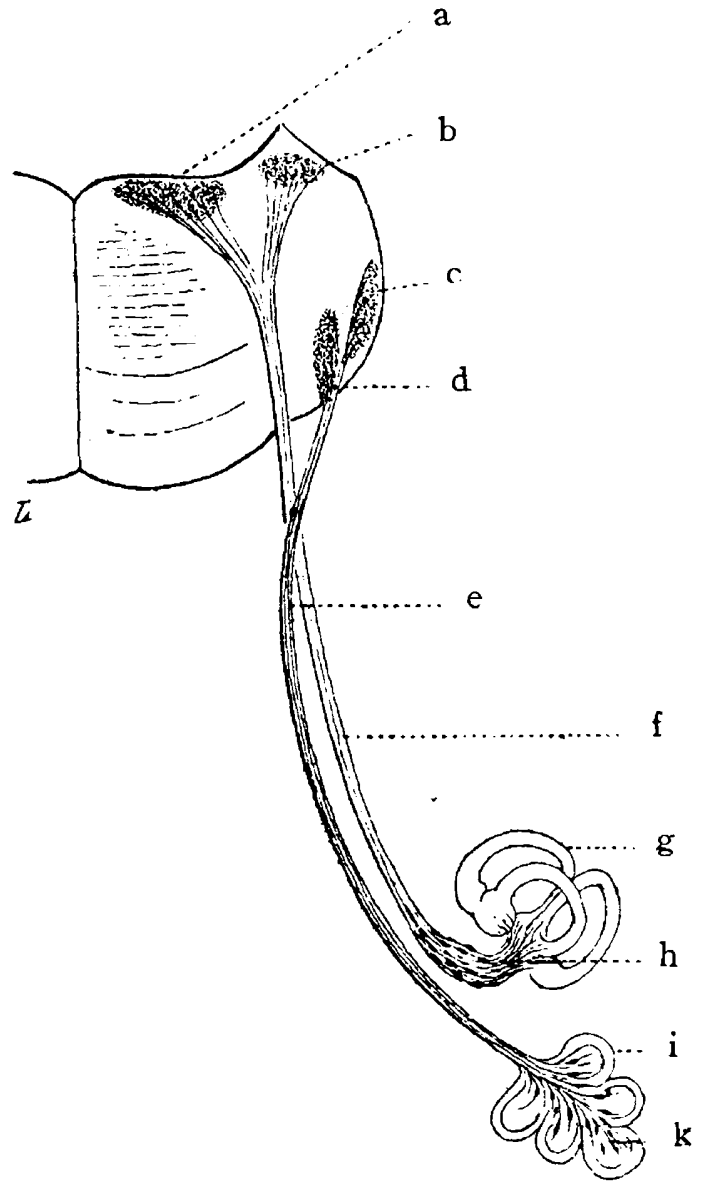

Fig. 16.-The origin and termination of the acoustic nerve: (a) nucleus posterior; (b) Deiter's nucleus; (c) tubereulum acusticum laterale; (d) nucleus anterior; (e) nervus cochlearis; (f) nervus vestibularis; (g) semicireular canals; (h) ganglion of Scarpa; (i) cochlea; (k) ganglion spirale, or ganglion of Corti. (l'oirier and Charpy.)

The ganglion acusticum at an early period separates into two ganglia. the ganglion of Scarpa and the ganglion of Corti, or ganglion spirale,

28. Van Gehuchten, A.: Les cellules du ganglion de Scarpa chez l'homme adulte, La Nêvrate, 1907-8, ix, 277. 
which are situated on the vestibular and cochlear divisions of the eighth nerve, respectively.

These ganglia are not infrequently involved in herpes zoster of the cephalic extremity, the simptoms of which vary according to the severity of the inflammatory reaction. In the milder form there are present only tinnitus aurium or a moderate degree of deafness (hypacusis). In the more severe forms, all the srmptoms of Ménière's syndrome may occur; i. e., labyrinthine deafness, disturbances of the equilibrium, nystagmus, nausea and romiting.

It seems to me not improbable that some of these cases have been described as Ménière's disease, also as toxic and "rheumatic" affections of the auditory nerve, the few herpetic vesicles escaping notice or having disappeared before the patient came under observation.

In my series of eighty-seven cases of herpes zoster, with facial paralysis, auditory symptoms were present in twenty-six. The acoustic symptoms preceded the palsy in five cases; in foutcen cases they appeared simultaneously. In the seven remaining cases, the relationship is not mentioned, or was doubtful.

I would emphasize those cases in which the auditory symptoms appeared before the facial paralysis, which show that the acoustic ganglia may be primarily involved; and are not secondarily affected by extension of the inflammatory process in the geniculate to the adjacent auditory nerve. It is, however, possible that such extension by contiguity may take place, causing the auditory symptoms in some of these cases.

The distribution of the eruption and the nature of the acoustic disturbances in this group of cases were as shown in Table 1.

Distribltiox of Ercption and Nature of Acoustic Disturbances in Posteriok Poliomyelitis of the ACditory Ganglia

\begin{tabular}{|c|c|c|c|c|}
\hline Herpes facialis & $\begin{array}{l}\text { 'Tinnitis. } \\
\text { Aurium. } \\
\text {.. }\end{array}$ & $\begin{array}{l}\text { Hyper- } \\
\text { acusis. } \\
\text {.. }\end{array}$ & $\begin{array}{l}\text { Hyp- } \\
\text { acusis. } \\
3\end{array}$ & $\begin{array}{l}\text { Ménière's } \\
\text { Syndrome. } \\
2\end{array}$ \\
\hline $\begin{array}{l}\text { Herpes facialis and oticus com- } \\
\text { bined } \ldots \ldots \ldots \ldots \ldots \ldots \ldots\end{array}$ & 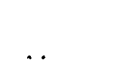 & $\ldots$ & 1 & 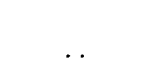 \\
\hline Herpes oticus $\ldots \ldots \ldots \ldots \ldots \ldots$ & . & 1 & 2 & 2 \\
\hline Herpes occipito-collaris . . . . . & 2 & . . & 9 & 1 \\
\hline $\begin{array}{l}\text { Herpes occipito-collaris and } \\
\text { oticus combined } \ldots \ldots \ldots \ldots \ldots\end{array}$ & . & . & 2 & 1 \\
\hline
\end{tabular}

Auditory symptoms may also accompany zona of the cephalic extremity without facial paralysis. This group of cases is adllitional proof of primary involvement of the acoustic ganglia, as it would be difficult to conceive of an inflammatory process in the geniculate ganglion passing orer to the eighth nerve without involving the motor fiber's of the serenth. 
'fable 2.-Distribution of the ERuption and Natire of the Acoustic Disturbances in Cephalic Zoxa Without Faciad Palsy

Herpes facialis with tinnitus and hypoacusis........... 2 cases

Herpes oticus with tinnitus and hypoacusis............ 4 cases

Herpes occipito-collaris with Ménière's syndrome.......... 1 case

Escat, ${ }^{20}$ in a recent communication, records 3 cases of auditory disturbances in herpes zoster of the face, in one of which facial palsy was also present. These auditory symptoms, he believes, are produced either by a trophoneurosis of the tubo-tympanic membrane or by a paralysis of accommodation, due to involvement of the tensor tympani. This explanation, however, is applicable only to a limited group of cases, in which the fifth nerve is the seat of the eruption, and the symptoms indicate an involvement of the conduction mechanism of the ear.

POSTERIOR POLIOMYELITIS OF THE AUDITORX GANGLIA WITHOUT

\section{HERPES ZOSTER}

If the auditory ganglia may be primarily involved in zona, in conjunction with an eruption in one or more of the zones of the cephalic extremity, may there not exist a group of cases in which these ganglia are alone affected, without eruptive manifestations?

The pathological studies of Head and Campbell have shown that the infiammatory process underlying herpes zoster is commonly localized in a single ganglion; and as the acoustic ganglia belong genetically to the spinal chain, and clinically are frequently involved in zona, it would seem reasonable to assume that the local inflanmatory reactions may be confined to these ganglia in certain cases. The clinical picture would then be characterized by the general symptoms and mode of onset of zona, but the eruptive manifestations would be replaced by symptoms indicating a more or less severe involvement of the cochlear and vestibular divisions of the auditory nerve. It is not improbable that cases answering this description have been considered under the heading of primary "rheumatic" affections of the eighth nerve. In the absence of definite pathological evidence, absolute proof of the existence of such a group is impossible. The demonstration of a lymphocytosis in the cerebrospinal fluid would, however, be of great diagnostic value in doubtful cases, because of its frequent occurrence in herpes zoster.

29. Escat: Troubles otiques fonctionelles et trophiques dans le zona total ou partiel du trijumeau, Bull. de Laryngol., Otol et Rhinol., 1908, xi, 173. 


\section{THE PARALYTIC COMPLICATIONS OF HERPES ZOSTER FACIALIS AND OCCIPITOCOLLARIS}

Facial palsy and auditory symptoms are also frequent complications of herpes facialis and herpes occipitocollaris. Such neural complications occurring when the eruption is situater in the trigeminal or upper cervical zones, are, I believe, produced by inflammatory reactions in the geniculate and auditory ganglia (multiple involvement of ganglia in zona). In my series of cases, the eruption was distributed in the zones of the trigeminal or upper cervical ganglia, in by far the larger proportion of cases.

Herpes occipitocollaris with facial palsy was noted in forty-eight cases. There was an associated hypacusis in nine; tinnitus aurium in two, and Ménière's syndrome in one case of this group.

Herpes facialis with facial palsy was observed in fifteen cases; of which three had an associated hypacusis and two presented the symptoms of Ménière's disease.

\section{REPORT OE PERSONAL CASES}

CASE 28.-Herpes Occipitocollaris with Facial Palsy.-(Referred by Dr. Theodore Janeway, St. Luke's Hospital.) A woman, aged 45. Onset June 9, 1909, with pains in the neck. On June 10 there appeared a widespread herpetic eruption in the right occipitocervical distribution (second, third, and fourth cervical) with great swelling and redness of the integument. During the first few days of the disease there was tinnitus aurium. On June 17 the right side of the face was paretic; palate innervation, taste and hearing were normal. On June 18, the facial palsy was complete; severe pain and burning in the eruptive area.

July 7 , the eruption had disappeared, but the facial palsy still persisted; no auditory symptoms (Fig. 17).

CASE 29.-Herpes Zoster Occipitocollaris with Facial Palsy.- (Referred by Dr. C. A. MacWilliams.) A man, aged 71, in good health. Onset Oct. 26, 1907, with an eruption of herpes zoster on the left side of the head and neck. The eruption was accompanied by smarting pain. On November 4 , the patient first noted a buzzing sensation in the left ear. 'This was not severe and did not last very long, and was followed by a left facial palsy. Examination showed typical peripheral facial palsy on the left side, complete in the lower and middle branches, partial in the upper branch; increased lacrimation of the left eye. Palate innervation, normal. 'The herpetic eruption was distributed over the occiput and neck on the left side. There were no sensory disturbances of the face or neck, with the exception of slight hypalgesia in the eruptive area. The corneal reflex was present on both sides. Hearing was good in both ears, but was not so distinct in the left as in the right. This was true of both the watch and tuning-fork. 'The patient recognized salt, sweet and sour on the left side of the tongue in the chorda area, but these sensations were not so prompt or so distinct as on the right side. Faradization of the left facial nerve produced a slight contraction in the orbicularis palpebrarum and frontalis on the left side, but practically no response in the lower branches. Direct faradization of the muscles of the left face produced a slight response in the muscles of the upper but none in those of the lower face. Post-herpetic pains were very mild and all trace of the palsy disappeared within a month. 
Case 30-Werpes Zostcr Occipitocollaris with Facial l'alsy.-(Referred from the Hudson Street Hospital, scrvice of Dr. Conner.) A man, aged 60, with spastic paraplegia of many years' duration of syphilitic origin. Onset of present illness, Feb. 19, 1906, with sharp shooting pains in the right side of the neck, occiput and mastoid region. A few days later an herpetic eruption appeared in the right oceipitocervical distribution. A right facial palsy developed within a week after the appearance of the eruption. There were no subjective disturbances of taste or hearing at the time of onset. The eruption cleared up in a few days, leaving numerous pigmented scars. Severe shooting pains with burning and itching still persisted.

On examination, May 16, 1906, there was still evident a right facial paralysis but with slight power of voluntary movements in all of the branches. Innervation

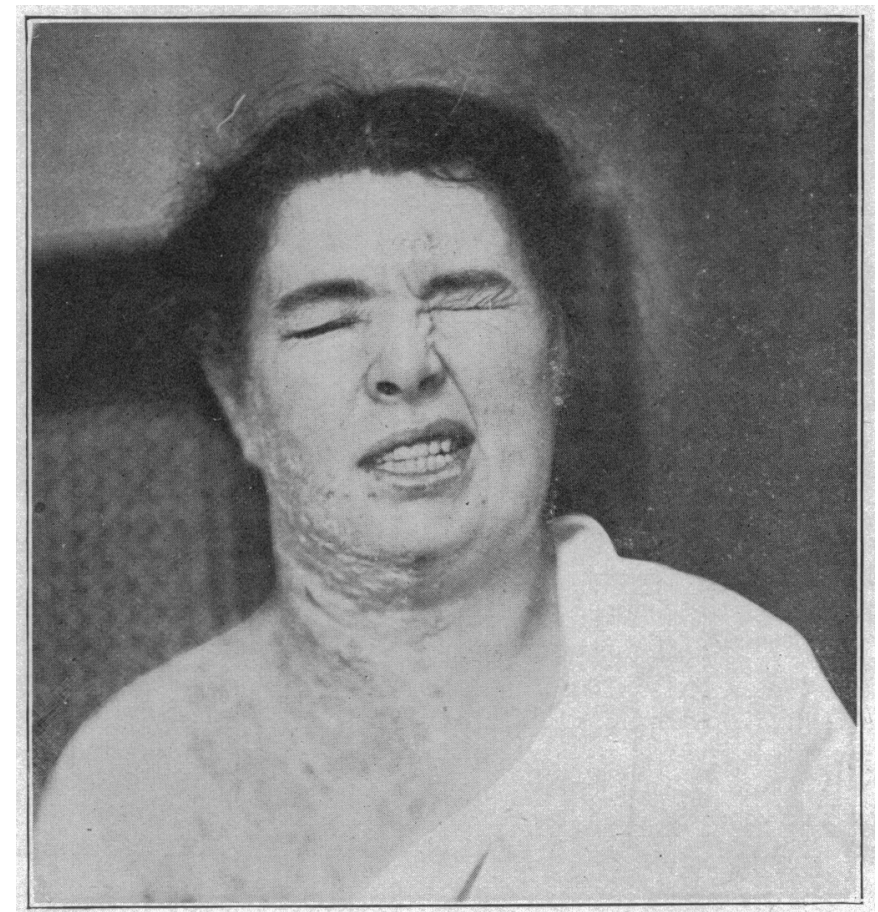
side.

Fig. 17 (Case 30).-Werpes occipitocollaris with facial palsy on the affected

of the palate was equal on the two sides; hearing was normal. Sensation of taste, while subjectively unimpaired, showed a distinct diminution when tested with solutions of salt, sugar and quinin. There were numerous areas of diminished sensation scattered over the right side of the neck and angle of the jaw, which correspond to the pignented areas. Electrical examinations showed partial reactions of degeneration of the muscles of the right face.

June 20, 1906, there were still numbness and itehing sensations in the right occipitocervical region with climinished sensibility. Lancinating pains were still present, but less severe and frequent. Taste was still obtunded on the right side. 
Voluntary innervation of the face had improved, especially in the upper branches; in the lower branches, beginning contracture was apparent. Partial reaction of degeneration still present.

CASE 31.-Herpes Zoster Facialis with Facial Palsy and Deafness.-(Observation by Kaufmann. ${ }^{3 *}$ ) A man, aged 34. Mild prodromal symptoms with fever and headache. On July 25, a redness of the left cheek and an eruption of herpes zoster, accompanied by headache, vertigo and repeated vomiting. July 26 , still headache and repeated vomiting. July 29 , sudden development of a left facial palsy with tinnitus and total deafness of the left ear. Palate normal; taste lost. August 24, patient had no vertigo, but constant tinnitus in the left ear. August 27, the facial palsy had cleared up but vertigo and disturbances of the equilibrium were still present. November 5, patient had recovered but with tinnitus and some diminution of hearing on the affected side.

Comment.-The occurrence of repeated vomiting before the onset of the auditory disturbances in this case suggests a probable involvement of the fibers of the vagus.

\section{CONCLUDING REMARKS}

From the evidence which has been presented, I believe that we are justified in isolating a large and varied group of cases, characterized by herpes zoster of the cephalic extremity, associated with facial palsy, auditory, glossopharyngeal, and pneumogastric symptoms, and in regarding them as constituting a well-defined clinical picture. A number of syndromes are thus united in a symptom-complex, having a common etiology and pathology.

The neural complications may oceur singly, or in various combinations, depending on the degree of the infection and the localization of the inflammatory process. Because of the tendency to invasion of more than one ganglion in cephalic zona, neural complications may occur even when the eruption is situated in the distribution of a ganglion situated above or below that causing the paralysis. In this event the nerve complication is caused by an inflammatory reaction in the ganglion of the affected nerve sufficient to cause a transient palsy, but not to produce an eruption.

The general symptoms may be very mild, or they may reach a high degree of severity, in consequence of which a considerable variation in the clinical picture results.

The neural symptoms are often singularly transient in their duration, all trace disappearing within a few days or a fortnight. Not infrequently permanent structural changes take place with persistent disturbance of function.

30. Kaufmann, D.: Ueber ein Fall von gleichseitiger, acut aufetretenen Erkrankungen des Acusticus, Facialis und Trigeminus, Ztschr. f. Ohrenh., 1896-7, xxx, 125. 
As is well known, paralytic complications may occur in other parts of the body in zona ; notably of the ocular nerves, but also in the distribution of the spinal nerves. These are, comparatively speaking, rare, probably because the inflammatory lesions are limited by the capsule of the ganglion, and in order to reach the motor nerves of the eye in Gasserian involvement, or the anterior root in that of the spinal ganglia, the inflammation must first break through this fibrous wall, or travel for some distance along the course of the sensory nerve. The capsule of the ganglion, therefore, forms a natural barrier and protection against the extension of the inflammatory process.

Anatomical conditions are different, however, in the ganglia under consideration. Here the fibers of the seventh, eighth, ninth and tenth nerves are in more immediate relation to the cell structures of their respective ganglia, and are not separated by an intervening fibrous wall.

For this reason very slight inflammatory reactions within these ganglia jeopardize their respective nerve fibers. This intimate association of ganglionic structure and nerve fibers would account, not only for those cases with light and transient symptoms, but also for those of a more severe grade, with lasting impairment of function.

In my study of this group of cases, I have encountered none in which a fatal issue could be attributed directly to the disease itself. It is well known that a unilateral lesion or section of the vagus is not necessarily dangerous to life; and as herpes zoster is usually unilateral pneumogastric involvement on one side would not be fatal. If, however, bilateral zona of the cephalic extremity should occur, involving the ganglia of the pneumogastric nerves on both sides dangerous symptoms, or even a fatal termination might result. It is perhaps significant in this connection to recall the wide-spread belief among the laity of the fatal tendency of bilateral shingles. Possibly we have here an explanation for a tradition which is common to all nations.

I would also emphasize the fact that in my study of this subject, I have found no cases with facial, auditory glossopharyngeal or pneumogastric nerve complications, accompanying an eruption of herpes zoster, except when situated on the cephalic extremity of the body; i. e., herpes facialis, oticus, pharyngis, laryngis lingualis, and occipitocollaris. That such neural complications do not accompany an eruption in the lower segments of the body is readily understood from the tendency of the posterior poliomyelitis to limit itself to a small series of ganglia, usually only one or two. In severe forms of infection, however, with extensive involvement of the cerebrospinal chain of ganglia there is no reason, theoretically, why cranial nerve palsies may not occur. 
I have attempted to differentiate the somatic zones of the geniculate, glossopharyngeal, and vagal ganglia on the external ear, as well as their intraoral, splanchnic zones within the buccal cavity. The demarcation of these zones is, however, only a preliminary one. It will, I hope, direct attention to the subject and may prove of value as a guide in future investigations. I believe that we have in the "herpes zoster method" an important key to the solution of this intricate problem.

It is my firm conviction that cases belonging to the group which I have just described are of much more frequent occurrence than might be inferred from the study of our literature. The reasons for which are to be found in the smallness and inaccessibility of the eruptive areas, making their detection difficult; or all traces of the eruption may have disappeared before the case comes under observation, when a retrospective diagnosis might be difficult or impossible.

It also seems probable, that some cases which are interpreted as rheumatic palsies of the face, palate, and even the larynx, may belong to this group; as well as toxic unilateral palsies of obscure origin. This, I believe, is also true of unilateral affections of the auditory nerve.

It is interesting to note, in this connection, that herpes zoster may apparently occur in an abortive form (Widal ${ }^{31}$ ), running its course with mild general symptoms, and a few neuralgic pains, but without the characteristic eruption. In cases of this doubtful nature, as well as in those rheumatic afiections of the facial and auditory nerves accompanied by neuralgic symptoms and localized neuralgic pains, the demonstration of a lymphocytosis of the cerebrospinal fluid would have a considerable diagnostic value, as recent investigations have shown that these are frequently increased in herpes zoster. ${ }^{32}$

20 West Fiftieth Street.

\section{SPECIAL Bibliograpil Y}

HERPES OTICUS

Anstie: Auricular Herpes, The Practioner, 1871, vii, 198.

Blake, C.: Herpes Zoster Auricularis, Boston Med. and Surg. Jour., J877, xcvi, 316.

Blau, L.: Herpes Auricularis, Encyclopädie der Ohrenheilkunde, Leipsic, 1900. Bürkner: Herpes auricularis, Lehrbuch der Ohrenheilkunde, 1892.

Buys: Eruption herpétique du pavillon, Bull. Soc. belge d'otol., laryngol. et de rhinol., 1898.

Chauveau, F.: Herpès du tympan, Ann. d. mal. de l'oreille, 1901, xxvii, 151.

31. Widal: Le Zona fruste, Jour. de mêd. et de Chir. prat., 1907, Ixxviii, 12.

32. Rallion, L.: De la lymphocytose du liquide cêphalo-rachidien dans le zona, Thèse de Paris, 1904. Avenier, R.: Le méningite zonateuse, Thèse de Paris, 1908, 
Chavanne, F.: Zona bilatêral isolê de l'oreille, Ann. d. mal de l'oreille, 1906, xxxii, 639.

Gruber, J.: Das Bläschenflechte am Ohre (Herpes auricularis) Monatsh. f. Ohrenh., 1875, ix, 53.

Gruber, J.: Herpes auricularis, Lehrbuch. der Ohrenheilkunde, Vienna, 1888. i, 848 .

Hall, F. de H.: Herpes of Mucous Membrane and Skin, Brit. Med. Jour., 1897,

Hasslauer: Herpes Zoster Oticus, Deutsch. mil.-ärzte Ztschr., 1905, xxxir, 261.

Ladreit de Lacharrière: Note sur l'herpès de l'oreille, Ann. d. mal. de l'oreille . . . 1877, iii, 349 .

Mignon: Zona otique, Bull. de. laryngol., otol., et rhinol., 1909, xii, 196.

Orbison, T. J.: Herpes of the Membrana Tympani, Jour. Nerv, and Ment. Dis., $1908, \operatorname{xxxv}, 500$.

Schwartz: Herpes Auricularis, Lehrbuch der Ohrenheilkunde, 1893.

Sommers, L. S.: Aural Herpes, Am. Med.-Surg. Bull., 1896, x, 503.

Urbantschitsch, V.: Herpes Auricularis, Lehrbuch f. Ohrenheilkunde, 1901.

Vail: Herpes Zoster Auris, Ann. Otol., Rhinol. and Laryngol., 1906, xv, 434.

\section{IIERPES PIIARYNGIS}

Achard and Castaigne: Zona cêphalique, Gaz. hebd. de méd. et chir., 1897, new series, ii, 1177 .

Bertholle: De l'herpès guttural, Union méd., 1866, xxx, 427.

Beregszaszy: Ueber Herpes Laryngis, Wien. med. Presse, 1879, xx, 1399.

Collie: Herpes with Tonsillitis, Lancet, London, 1890, ii, 340.

Davy, A. C. M.: Contribution a l'êtude de l'herpès des muqueuses de l'herpès du larynx, 'These de Paris, 1882.

Féron: L'angine herpêtique, Thèse de Paris, 1858.

Fournier, H.: Zona des muqueuses, Jour. de mal. cut. et syph., 1891, iii, 419.

Frantzen: Fall von Herpes zoster des Gesichts und weichen Gaumens, Monatschr. f. prakt. Dermat., 1895, xx, 396.

Heller: Ein Fall von Herpes Pharyngis, Wien. klin. Wehnschr., 1894, viii, 539.

Irsai: Herpes Pharyngis Laryngis et Linguae, Pest. Med. Chir. Presse, 1903, xxxix, 554 .

Kahn, M.: Zur Kasuistik des Herpes Gutturalis, Internat. klin. Runschau, 1890 , iv, 667 .

Keanessy: Angina herpetica, Internat. Centralbl. f. Laryngol., 1889-90-vi, 56.

Lermoyez and Barozzi, J.: Zona double bueco-pharyngien, Ann. d. mal. de l'oreille, 1897, xxiii, 233.

Lubliner: Herpes Pharyngis, Arch. f. Dermat. und Syph., 1895, xxxii, 423.

Mahn: L’herpès rêtropharyngien, Méd. mod., 1906, xvii, 195.

MeBride: Herpes Zoster of the Hard Palate, Edinburgh, Clin. and Path. Jour., $1884, \mathrm{i}, 745$.

Ollivier, A.: De l'angine herpétique, Compt. rend. Soc. de biol., 1871 (1873), xxiii, 277; L'angine herpétique, Semaine, méd., 1884, iv, 357.

Wodon, J.: Cas d'angine herpétique, Presse méd. belge, 1894, xlvi, 137.

\section{HERPES LARYNGIS}

Bettmann: Ueber Herpes Laryngis, Berl. klin. Wehnschr., 1902, xxxix, 837.

Boulai, J.: Herpes zosterriforme primitif du larỵx, Arch. internal de laryngol., 1904, xviii, 149.

Brindel, A.: De l'herpès du larynx, Rev. de larỵng., d'otol. et de rhinol., 1895, $\mathrm{xv}, 233$. 
Castañeda, R.: Herpes laringeo idiopâtico, Oto-Rino-Laringologia Española, $1898-9$, i, 325 .

Fischer, F.: Ueber Pseudoherpes des Pharynx und Larynx, Berl. klin. Wehnschr., 1884, xxi, 798.

Glas, E.: Ueber Herpes laryngis, Berlin. klin. Wchnschr., 1906, xliii, 194-233.

Gronot: Herpès opalin de la gorge et du Iarynx, Concours méd., 1884, vi, 643. Heymann: Handbuch der Laryngologie, 1898, i.

Lake: Herpes of the Epiglottis, Jour. Laryngol., Rhinol. and Otol., 1901, xvi, 63.

Meyer, R.: Die phlyctänulïre Stimmbandentzïndung, Berl. klin. Wchnschr., 1879 , xvi, 609 .

Scheff, G.: Herpes Jaryngis, Allg. Wien. med. Ztg., 1881, xxvi, 475.

Scholefeld: Case of Herpes of the Larynx, Lancet, 1892, i, 251.

Secretan, L.: Herpès laryngis, Ann. d. mal. de l'oreille, 1895, xxi, Part 2, 113.

Stepanow, E. M.: Einige Bemerkungen über zwei Falle von Herpes Laryngis, Monatschr. f. Ohrenh., 1885, xix, 237.

\section{HERPES LINGUE AND FACIAL PALSY}

Bernack: Cited by Despaigne: Paralysie faciale, Thèse de Paris, 1888.

Eichhorst, H.: Herpes zoster und Facialislïhmung, Centralbl. f. inn. Med., 1897 , xviii, 425.

Hess: Ein Fäll von Facialislähmung, Virchow's Areh. f. path. Anat., 1889, ii, s. 120 .

Kern: Cited by Despaigne: Paralysie, Thèse de Paris, 1888.

Remak, E.: Zur Pathogenese des peripherischen Facialparalyse gelegentlich. complic. Herpes zoster, Centralbl. f. Nervenh., 1885, viii, 145.

Siegheim: Herpes zoster im Gebiete des Nervus facialis dexter, Monatschr. f. prakt. Dermat., 1895 , xx, 396.

\section{herpes zoster of CePhalic EXTREMity With SEVENTh YerVe PALSY}

Axenfeld: Herpes zoster ophthalmicus mit Fazialislähmung als Unfallfolge, München. med. Wchnschr., 1906, liii, 2417.

Barthelémy: A propos de la névrite du zona, Bull. Soc. Franç. de dermat. et de syph., 1891, ii, 382 .

Besnier: Cited by Gaudu: Paralysie faciale, Thèse de Paris, 1901.

Cobb, A.: A Case of Herpes Zoster, Boston Med. and Surg. Jour., 1869, 1xxx, 95.

Cousot: Pathogénie du zona et paralysies, Bull. de l'Acad. ray. de méd., 1904, 296.

Darabseth, N. B.: A Case of Bell's Paralysis Following Herpes Zoster; Recovery, Lancet, London, 1894, i, 1129. 1888.

Despaigne, G.: Etudes sur la paralysie facial périphêrique, Thèse de Paris,

Ebstein, W.: Zur Lehre von den nervösen Störungen beim Herpes zoster (Beobachtung 10), Virchow's Arch. f. path. Anat., 1895, cxxxix, 512.

Fay, W.: Paralysis of the Right Facial Nerve, with Herpes Zoster of Second Division of the Fifth Nerve, Brit. Med. Jour., 1883, ii, 1246.

Fraser, E. H.: A Case of Facial Paralysis Associated with Herpes Zoster, Lancet, London, 1904, i, 18.

Frich, O.: Ein Fall von Herpes zoster cervicalis compl. mit totalen Facialislähmung, Monatsh., f. prakt. Dermat., 1898, xxvi, 375.

Fysche, J. C., and Hunter, A. W.: Herpes Zoster and Facial Palsy, Montreal Med. Jour., 1907, xxxvi, 185. 
Gaudu, E.: Contribution à l'étude de la paralysie faciale dans le zona, Thèse de Paris, 1901.

Greenough: Herpes Zoster and facial Zoster, Boston Med. and Surg. Jour., 1869, lxxix, 401.

Herpes Zoster and Paralysis, Editorial in The Hospital, 1907, new series, ii, 85.

Hervouet: Sur un cas de zona, Gaz. méd. de Nantes, 1891-92, x, 138.

Hewlett, A. W.: Motor Complications of Herpes Zoster, California State Jour. Ifed., 1906, iv, 119 .

Klippel and Aynaud: La paralysie faciale zostérienne, Rev gén. de clin. et de thérap., Jour. d. Pract., 1899, xiii, 225.

Letulle: Cited by Gaudu; Paralysie Faciale, Thèse de Paris, 1901.

Menke, W.: Beitrage zur Path. der sogenannten refrigeratorischen Facialislähmung, Diss., Berlin, 1890.

Montgomery, D. W.: Zoster Ophthalmicus, with Facial Palsy, Occidental Med. Times, 1900, xiv, 109.

Morrice: Herpes Zoster and Facial Palsy, St. Bartholomew's Hosp. Rep., $1897, \mathrm{xxxii}, 167$.

Murphy, H. H.: Herpes Zoster of the Face with Paralysis, Brit. Med. Jour, $1897, \mathrm{ii}, 466$.

Neilson: Herpes Zoster und Facialis-Lähmung, Monatsh. f. prakt. Dermat., 1898, 375.

Perrin, L.: Paralysie faciale périphérique consécutive à un zona cervicooccipital, Marseille méd., 1892, xxix, 580.

Rabbé: Contribution a l'étude de la paralysie faciale dans le zona, Thèse de Paris, 1896.

Rugani: L'herpès et paralysie faciale, Boll. d. mal. d. orecchio d. gola e d. naso, 1905 , xxiii, 73.

Spencer, H. A.: Bell's Paralysis Occurring with Herpes Zoster, Lancet, 1894, i, 1447 .

Strubing, P.: Herpes Zoster und Lähmungen motorischen Nerven, Deutsch. Arch. f. klin. Med., 1885, xxxvii, 513.

Tomka, S.: (Nervus Facialis) Arch. f. Ohrenh., 1900, xlix, 28.

Truffi: Un caso raro di herpes zoster, Gior. ital. d. mal. ven. e. d. pelle, 1898, xxxiii, 610 .

Tryde, C.: Bemerkungen über Facialisparalyse, Schmidt's Jahrbuch, 1872, cliv. 272.

Van Someren, G. A.: A Case of Herpes Zoster with Long-Persisting Neuralgic Pain and Bell's Paralysis, Lancet, London, 1895, i, 1372.

Waterman, D. A.: Facial Paralysis; A Study of 335 Cases, Jour. Nerv. and Ment. Dis., 1909, xxxvi, 65.

Weatherhead, E.: Herpes of the Second and Third Cervical Posterior Root Areas, Accompanied by Facial Paralysis, Brit. Med. Jour., 1909, p. 402.

Winternitz, R.: Herpes Zoster, München. med. Wchnschr., 1904, li, 1718.

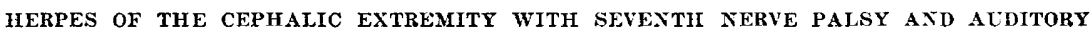
SYMPTOMS

Achard, L.: Contribution a l'etude des affections multiples des nerfs craniens compliquant le zona, Thèse de Paris, 1900.

Von Barensprung: Beiträge zur Kenntnisse der Herpes Zoster, Charité Annalen, 1863, 63 .

Barnes, S. A.: Herpes Zoster of the Third and Fourth Cervical Distribution, Lancet, London, 1902, ii, 1197.

Berger, A.: Ueber Polyneuritis cerebralis ménièriformis, Neurol. Centralbl., 1905 , xxiv, 844 . 
Bronson, E. B.: Zoster and Paralysis, New York Polyelin., 1893, ii, 135.

Burin-Desroziers, E.: Zona de la deuxième branche du trijumeau, Thèse de Paris, 1904.

Busch, J. P.: Herpes Zoster of the Third and Fourth Cervical Distribution, Lancet, London, 1902, ii, 1197.

Cassasus: Deux cas de paralysie faciale consécutive au zona cervical, Jour. de méd. de Bordeaux, 1906, xxxvi, 413.

Champion, L. J.: Manifestations à distance dans le zona, Thèse de Paris, 1900.

Cheatle, A. H.: A Case of Deafness, Perversion of Taste and Facial Paralysis Associated with Herpes, Jour. Laryngol., 1901, xvi, 91.

Feré: Hallucinations unilatérales homonymes dans le zona de la face, Compt. rend. Soc. de biol., 1892, xliv, 349.

Frankl-Hochwart, L.: Der Ménière'sche Symptomen-Complex, Specielle Pathologie und Therapie (Nothnagel), 1895, xi, Th. 2, Abt. 3, p. 4.

Gibson, J. L.: Case of Herpes Zoster, Accompanied by Paralysis of the Auditory and Facial Nerves, Australas. Med. Gaz., 1895, xiv, 181.

Gradenigo: Herpès zoster otique, Ann. d. mal. de l'oreille, 1908, xxxiv, 258.

Grassmann: Herpes Zoster mit gleichseitiger Facialislähmung, Deutsch. Arch. f. klin. Med., 1897, lix, 616.

Hammerschlag: Beitrag zur Casuistik der multiplen Hirnnervenerkrankungen, Arch. f. Ohrenh., 1898, xlv, 1.

Hammerschlag: Die rheumatischen Affectionen des Gehörnerven-Apparates, Arch. f. Ohrenh., 1901, lii, 1.

Hoffmann, D.: Ueber ein Fall von gleichseitiger, acut aufgetretener Erkrankung das Acusticus, Facialis und Trigeminus, Ztschr. f. Ohrenh., 1896-7, xxx, 125.

Kaufmann, D.: Die rheumatischen Affectionen des Gehörnerven-Apparats., Arch. f. Ohrenh., 1901, lii, 1.

Kaufmann, J.: Zur Lehre von der peripherischen Facialislähmung, Deutsch. Ztschr. f. Nervenheilk., 1894, v, 72.

Klippel and Aynaud: La paralysie faciale zostérienne, Rev. gên. des Clin. et de Ther. Jour. d. Pract., 1899, xiii, 225.

Lannois, M.: Troubles auditifs dans le zona, Ann. d. mal. de l'oreille, 1904, xxx, 2217; Zona avec Paralysie Faciale, Lyon méd., 1899, xci, 481; Troubles auditifs dans le zona, Congres (VII) Internat. d. Otol., Bordeaux, 1904, 240.

Reymond, H.: Herpes zoster de l'oreille, Gaz. méd. de Paris, 1908, viii.

Voigt, E.: Ueber Complication von Herpes Zoster occipito-collaris mit schwerer peripherer gleichseitiger Facialis-Paralyse, St. Petersburg. med. Wchnschr., 1884, new series, i, 449. 